


\section{Methodebeschrijving voor de controle van het koper- en zinkgehalte in rantsoenen voor vleeskuikens op basis van strooiselmest}

J. van Harn en P. Bikker 
Harn, J. van en P. Bikker, 2018. Methodebeschrijving voor de controle van het koper- en zinkgehalte in rantsoenen voor vleeskuikens op basis van strooiselmest. Wageningen, RIKILT Wageningen University \& Research, RIKILT-rapport 2018.006. 44 blz.; 6 fig.; 15 tab.; 34 ref.

Projectnummer: 1227186001

BAS-code: WOT-02-004-013

Projecttitel: Juridische eisen met betrekking tot analyse- en bemonsteringsmethoden gebruikt in het opsporingsonderzoek van diervoeders en diervoedergrondstoffen

Projectleider: P. Bikker

Dit rapport is gratis te downloaden op https://doi.org/https://doi.org/10.18174/460536 of op www.wur.nl/rikilt (onder RIKILT publicaties).

(C) 2018 RIKILT Wageningen University \& Research, instituut binnen de rechtspersoon Stichting Wageningen Research. Hierna te noemen RIKILT.

Het is de opdrachtgever toegestaan dit rapport integraal openbaar te maken en ter inzage te geven aan derden. Zonder voorafgaande schriftelijke toestemming van het RIKILT is het niet toegestaan:

a. dit door RIKILT uitgebrachte rapport gedeeltelijk te publiceren of op andere wijze gedeeltelijk openbaar te maken;

b. dit door RIKILT uitgebrachte rapport, c.q. de naam van het rapport of RIKILT, geheel of gedeeltelijk te doen gebruiken ten behoeve van het instellen van claims, voor het voeren van gerechtelijke procedures, voor reclame of antireclame en ten behoeve van werving in meer algemene zin;

c. de naam van RIKILT te gebruiken in andere zin dan als auteur van dit rapport.

Postbus 230, 6700 AE Wageningen, T 03174802 56, E info.rikilt@wur.nl, www.wur.nl/rikilt. RIKILT is onderdeel van Wageningen University \& Research.

RIKILT aanvaardt geen aansprakelijkheid voor eventuele schade voortvloeiend uit het gebruik van de resultaten van dit onderzoek of de toepassing van de adviezen.

RIKILT-rapport 2018.006

Verzendlijst:

- NVWA: C.J.A.M.van der Meijs

- Adviescommisie Diervoeders: R.D. van Buuren, M.G.M. van Creij, F.B. Leijdekkers, J. Schans, H.A. van der Schee, A.D. Wentzel, K. Zwaagstra, E.S. Rikkoert, E.F. Enning, E.J. Laurensse 


\section{Inhoud}

$\begin{array}{ll}\text { Woord vooraf } & 5\end{array}$

$\begin{array}{ll}\text { Samenvatting } & 7\end{array}$

1

$\begin{array}{ll}\text { Inleiding } & 9\end{array}$

1.1 Achtergrond $\quad 9$

1.2 Eerdere ervaring bij varkens 9

$\begin{array}{ll}1.3 \text { Methode voor vleeskuikens } & 10\end{array}$

$\begin{array}{ll}\text { Houderij van vleeskuikens } & 11\end{array}$

2.1 Algemeen 11

2.2 Stalbroed - het laten uitkomen van kuikens in de stal 13

$\begin{array}{lll}2.3 & \text { Strooisel } & 14\end{array}$

$3 \quad$ Koper en zink in de voeding

3.1 Rol van koper en zink in het dier $\quad 15$

3.2 Koper- en zinkbehoefte van vleeskuikens 15

3.3 Maximale gehalten aan koper en zink 16

3.4 Bronnen van koper en zink in het voer 16

$\begin{array}{lll}3.5 & \text { Koper en zink in praktijkvoeders } & 17\end{array}$

$\begin{array}{lll}3.6 & \text { Bijdrage drinkwater supplementen aan de excretie } & 17\end{array}$

4 Ontwikkeling van de methodiek $\quad 20$

4.1 Algemene beschrijving en aanpak $\quad 20$

$\begin{array}{lll}4.2 & \text { Drogestof verteerbaarheid van het voer } & 21\end{array}$
4.2.1 Methode

4.2.2 Resultaten

4.3 De vastlegging van koper en zink in vleeskuikens $\quad 21$

$\begin{array}{ll}4.3 .1 \text { Methode } & 21\end{array}$

4.3.2 Resultaten $\quad 22$

4.4 Groeiprestaties van de dieren en bezettingsdichtheid $\quad 24$

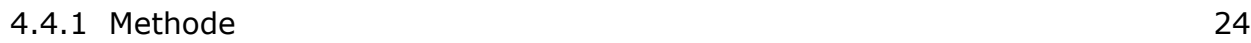

4.4.2 Resultaten $\quad 24$

4.4.3 Praktische uitvoering $\quad 24$

4.5 Samenstelling en gebruik van strooiselmateriaal $\quad 25$

$\begin{array}{ll}4.5 .1 \text { Methode } & 25\end{array}$

4.5.2 Resultaten $\quad 25$

$\begin{array}{ll}\text { 4.5.3 Praktische uitvoering } & 27\end{array}$

$\begin{array}{lll}4.6 & \text { Gevoeligheidsanalyse } & 27\end{array}$

$5 \quad$ Monstername en modelvalidatie $\quad 29$

$\begin{array}{lll}5.1 & \text { Methode } & 29\end{array}$

5.1.1 Variatie in strooiselmest binnen een stal $\quad 29$

$\begin{array}{ll}5.1 .2 \mathrm{Cu} \text { en Zn gehalten in strooiselmest } & 29\end{array}$

$\begin{array}{ll}5.1 .3 \text { Validatie } & 30\end{array}$

$\begin{array}{lll}5.2 & \text { Resultaten } & 30\end{array}$

5.2.1 Variatie in strooiselmest binnen een stal $\quad 30$

5.2.2 Cu en Zn gehalten in strooiselmest $\quad 30$

5.2.3 Berekende en geanalyseerde gehalten 31 
Bijlage 1 Het Vleeskuikenbesluit 35

$\begin{array}{lll}\text { Bijlage } 2 & \text { Voetzoollaesies } & 36\end{array}$

$\begin{array}{lll}\text { Bijlage } 3 & \text { Drinkwatersupplementen } & 37\end{array}$

$\begin{array}{lll}\text { Bijlage } 4 & \text { Gemiddelde voersamenstelling } & 39\end{array}$

Bijlage 5 Cu en Zn in vleeskuikens $\quad 40$

$\begin{array}{lll}\text { Bijlage } 6 & \text { Standaard curve } & 41\end{array}$

$\begin{array}{lll}\text { Bijlage } 7 & \text { Bemonstering strooiselmest } & 42\end{array}$ 


\section{Woord vooraf}

Koper $(\mathrm{Cu})$ en zink $(\mathrm{Zn})$ zijn essentiële spoorelementen en moeten daarom in voldoende mate in het voer aanwezig zijn om een efficiënte productie en een goed welzijn van landbouwhuisdieren mogelijk te maken. Om in de behoefte aan deze spoorelementen te voorzien worden deze aan de meeste mengvoeders toegevoegd. Aangezien relatief weinig $\mathrm{Cu}$ en $\mathrm{Zn}$ door het dier wordt vastgelegd wordt het grootste deel van de opgenomen hoeveelheid weer uitgescheiden via de mest. Bij aanwending van de mest komen $\mathrm{Cu}$ en $\mathrm{Zn}$ in het milieu terecht. Om te voorkomen dat er teveel $\mathrm{Cu}$ en $\mathrm{Zn}$ in het milieu terecht komt zijn er wettelijke eisen gesteld aan het gehalte van deze spoorelementen in het voer. Voor vleeskuikens is bepaald dat het rantsoen maximaal $25 \mathrm{mg} \mathrm{Cu}$ en $120 \mathrm{mg}$ Zn per kilogram mag bevatten. De Nederlandse Voedsel- en Warenautoriteit (NVWA) heeft tot taak er op toe te zien dat deze wettelijke normen niet worden overschreden. Dit zou bijvoorbeeld het geval kunnen zijn door het gebruik van supplementen in voer en drinkwater naast het reeds aanwezige $\mathrm{Cu}$ en $\mathrm{Zn}$ in de gebruikte (meng)voeders. De vraag in deze studie was daarom hoe gecontroleerd kan worden of de maximaal toegelaten gehalten aan $\mathrm{Cu}$ en $\mathrm{Zn}$ in de rantsoenen voor vleeskuikens zijn overschreden. De analyse van het aanwezige voer en drinkwater is daarbij uiteraard een goed hulpmiddel, maar dit is slechts een momentopname en geeft geen inzicht in eventuele overschrijding in de voorgaande periode. De vraag in deze studie was daarom of het mogelijk is via bemonstering van strooiselmest te controleren of de maximaal toegelaten gehalten aan $\mathrm{Cu}$ en $\mathrm{Zn}$ in de rantsoenen voor vleeskuikens zijn overschreden. In deze rapportage wordt hiervoor een methode beschreven en besproken welke onzekerheden deze werkwijze met zich meebrengt. Dit onderzoek is uitgevoerd door RIKILT Wageningen University \& Research, in opdracht van de NVWA en gefinancierd door het Ministerie van Economische Zaken, in het kader van de wettelijke onderzoekstaken, programma 2 'Voedselveiligheid' (WOT-2) (projectnummer WOT-02-004-013).

Tijdens de uitvoering van dit onderzoek was het toegelaten supplementen met $\mathrm{Cu}$ en/of $\mathrm{Zn}$ toe te voegen aan drinkwater, mits de toegelaten dosering op rantsoenbasis (voer en drinkwater) niet werd overschreden. Op 13 augustus 2018 is echter de Uitvoeringsverordening (EU) 2018/1039 van kracht geworden, welke verbiedt supplementen met $\mathrm{Cu}$ aan drinkwater toe te voegen. Dit betekent dat na een overgangsperiode tot 13 augustus 2019 om bestaande voorraden te gebruiken, toevoeging van $\mathrm{Cu}$ aan drinkwater niet langer is toegelaten. Voor de implementatie van de in dit rapport beschreven methode heeft deze verandering in regelgeving geen consequenties. De methode is bedoeld en kan worden gebruikt om overschrijding van de totale inname van $\mathrm{Cu}$ en $\mathrm{Zn}$ door vleeskuikens te controleren. Het maximaal toegelaten gehalte aan $\mathrm{Cu}$ in het rantsoen voor vleeskuikens is in Uitvoeringsverordening (EU) 2018/1039 ongewijzigd 25 mg/kg. 


\section{Samenvatting}

De Nederlandse Voedsel- en Warenautoriteit (NVWA) heeft tot taak het correct gebruik van koper (Cu) en zink $(Z n)$ in voeders van pluimvee te bewaken. De vraag in deze studie was daarom hoe gecontroleerd kan worden of de maximaal toegelaten gehalten aan $\mathrm{Cu}$ en $\mathrm{Zn}$ in de rantsoenen voor vleeskuikens zijn overschreden. De analyse van het aanwezige voer en drinkwater is daarbij uiteraard een goed hulpmiddel, maar dit is slechts een momentopname en geeft geen inzicht in eventuele overschrijding in de voorgaande periode. Daarom werd gezocht naar een andere, aanvullende benadering. De NVWA heeft RIKILT Wageningen University \& Research gevraagd in navolging van een eerder ontwikkelde methodiek voor varkens zo mogelijk een methode te ontwikkelen om op basis van de excretie in de mest het gebruik van $\mathrm{Cu}$ en $\mathrm{Zn}$ bij vleeskuikens te controleren.

Koper en zink zijn essentiële spoorelementen en moeten daarom in voldoende mate in het voer aanwezig zijn om een efficiënte productie en een goed welzijn van landbouwhuisdieren mogelijk te maken; een tekort leidt tot gezondheidsproblemen en lagere dierprestaties. Aan de meeste mengvoeders wordt $\mathrm{Cu}$ en $\mathrm{Zn}$ toegevoegd om in de behoefte van de dieren aan deze elementen te voorzien. Aangezien relatief weinig $\mathrm{Cu}$ en $\mathrm{Zn}$ door het dier wordt vastgelegd wordt het grootste deel van de opgenomen hoeveelheid weer uitgescheiden via de mest. Bij aanwending van de mest komen deze mineralen in het milieu terecht. Mede om deze reden worden er eisen gesteld aan maximaal toegestane gehalten aan $\mathrm{Cu}$ en $\mathrm{Zn}$ in het rantsoen. Voor vleeskuikenvoeders geldt dat deze maximaal $25 \mathrm{mg} \mathrm{Cu}$ en $120 \mathrm{mg} \mathrm{Zn}$ per kilogram mogen bevatten. Er worden geen separate eisen gesteld aan maximale gehalten aan $\mathrm{Cu}$ en $\mathrm{Zn}$ in (drinkwater)supplementen omdat deze tot het rantsoen worden gerekend ${ }^{1}$. Sommige van deze supplementen bevatten aanzienlijke hoeveelheden $\mathrm{Cu}$ en/of $\mathrm{Zn}$, waardoor het gebruik ervan kan resulteren in een overschrijding van de maximale $\mathrm{Cu}$ en $\mathrm{Zn}$ gehalten. De indruk bestaat dat het gebruik van wateradditieven is toegenomen, mede als gevolg van veranderde regelgeving, zoals de implementatie van de Europese welzijnswetgeving en het convenant antibioticaresistentie dierhouderij.

Voor vleeskuikens is het, in tegenstelling tot varkens, moeilijk om de verstrekte hoeveelheid $\mathrm{Cu}$ en $\mathrm{Zn}$ via het rantsoen te relateren aan het $\mathrm{Cu}$ en $\mathrm{Zn}$ gehalte in de verse mest. Redenen hiervan zijn dat vleeskuikens worden gehuisvest op strooisel waardoor verse mest na excretie meteen wordt vermengd met strooisel en dat additieven/supplementen in de vleeskuikenhouderij niet continue worden gebruikt, waardoor analyse van verse mest als momentopname waarschijnlijk geen representatief beeld van $\mathrm{Cu}$ en $\mathrm{Zn}$-gebruik in de voorgaande periode geeft.

Voor de vleeskuikenhouderij is dus een andere methodiek nodig. In deze studie is een model ontwikkeld om het $\mathrm{Cu}$ - en $\mathrm{Zn}$-gehalte in het rantsoen te berekenen vanuit $\mathrm{Cu}$ en $\mathrm{Zn}$ gehalten in de strooiselmest. Uitgaande van de maximale toegestane $\mathrm{Cu}$ - en $\mathrm{Zn}$-gehalten in het voer kan berekend worden hoeveel $\mathrm{Cu}$ en $\mathrm{Zn}$ er op een bepaald moment in de strooiselmest aanwezig mag zijn. Overschrijding van deze berekende hoeveelheid betekent dat er te veel koper en zink verstrekt is aan de dieren. Er zijn echter een aantal onzekere factoren en variatiebronnen waaronder: koper- en zinkgehalte van het voer, drogestof-verteerbaarheid van voer, koper- en zinkgehalte in de dieren op verschillende leeftijden, de bijdrage aan $\mathrm{Cu}$ en $\mathrm{Zn}$ vanuit strooiselmateriaal, de leeftijd van kuikens op moment bezoek en monstername, en de representativiteit van het strooiselmestmonster.

In deze studie zijn een aantal van deze variatiebronnen gekwantificeerd.

- Er zijn monsters van vleeskuikens, gedood op verschillende leeftijden, geanalyseerd om het $\mathrm{Cu}$ en Zn-gehalte in de dieren te bepalen.

- Er zijn monsters verzameld van de meest gebruikte soorten strooiselmateriaal waarin het $\mathrm{Cu}$ en $\mathrm{Zn}$ gehalte is bepaald.

- Er zijn bij een aantal vleeskuikenbedrijven volgens een vast protocol monsters van de strooiselmest genomen om de variatie in $\mathrm{Cu}$ - en $\mathrm{Zn}$-gehalte binnen en tussen stallen in beeld te krijgen.

1 Conform Uitvoeringsverordening (EU) 2018/1039 is het toevoegen van supplementen met Cu aan drinkwater vanaf 13 augustus 2018, met een overgangsperiode tot 13 augustus 2019 voor bestaande voorraden, niet meer toegelaten. 
- $\mathrm{Er}$ is een inventarisatie gemaakt van veel gebruikte drinkwatersupplementen, het Cu- en Zn-gehalte in deze producten en de mogelijke bijdrage aan het $\mathrm{Cu}$ - en $\mathrm{Zn}$-gehalte in het rantsoen.

- Op basis van eerder onderzoek en literatuur is een inschatting gemaakt van de verteerbaarheid van de drogestof van een gemiddeld rantsoen voor vleeskuikens.

Met behulp van deze gegevens is een spreadsheetmodel ontwikkeld waarmee het Cu- en $\mathrm{Zn}$-gehalte in de strooiselmest kan worden berekend op basis van de stalbezetting, de dierprestaties (voeropname, groei, uitval), de vastlegging van $\mathrm{Cu}$ en $\mathrm{Zn}$ in het lichaam, het aandeel en het $\mathrm{Cu}$ - en $\mathrm{Zn}$-gehalte in schoon strooisel, de drogestof verteerbaarheid van het voer en eventuele broei van mest. Met dit model is vervolgens het verwachte $\mathrm{Cu}$ - en $\mathrm{Zn}$-gehalte in strooiselmest berekend voor gemiddelde omstandigheden en er is een gevoeligheidsanalyse voor de eerdergenoemde variatiebronnen uitgevoerd. Daarnaast is voor een aantal vleeskuikenbedrijven het verwachte Cu en Zn-gehalte vergeleken met het geanalyseerde gehalte op basis van het eerdergenoemde monsterprotocol.

Het Cu- en Zn-gehalte in strooiselmest neemt in de eerste weken geleidelijk toe door een afnemende invloed van het aandeel strooisel in de strooiselmest. Het verdient daarom aanbeveling de controle uit te voeren na circa 30 dagen om de invloed van dit verdunningseffect van strooisel te beperken. Het gemiddeld berekende $\mathrm{Cu}$ - en Zn-gehalte in de strooiselmest bedroeg respectievelijk 94 en $422 \mathrm{mg} / \mathrm{kg}$ drogestof bij een leeftijd van 35 dagen. De invloed van de variatie in groeiprestaties, het Cu-gehalte vastgelegd in het lichaam, Cu-gehalte in strooiselmateriaal, de bezettingsdichtheid (dieren/ $\mathrm{m}^{2}$ ) en uitval is relatief gering. Variatie in de hoeveelheid strooiselmateriaal en de drogestof verteerbaarheid van het voer heeft een grote invloed op het $\mathrm{Cu}$ - en $\mathrm{Zn}$-gehalte in de drogestof en behoeft aandacht. De vergelijking van het berekende en geanalyseerde gehalte aan $\mathrm{Cu}$ en $\mathrm{Zn}$ in strooiselmest op enkele bedrijven liet een goede overeenkomst zien.

Op basis van de hier beschreven resultaten lijkt analyse van strooiselmest een geschikte methode voor het bepalen van eventueel overschrijding van de maximaal toegelaten gehalten aan $\mathrm{Cu}$ en $\mathrm{Zn}$ in het rantsoen. Voor de praktische toepassing zijn een aantal adviezen gegeven. 


\section{$1 \quad$ Inleiding}

\section{$1.1 \quad$ Achtergrond}

Koper $(\mathrm{Cu})$ en zink $(\mathrm{Zn})$ zijn essentiële spoorelementen en moeten daarom in voldoende mate in het voer aanwezig zijn om een efficiënte productie en een goed welzijn van landbouwhuisdieren mogelijk te maken. Om in de behoefte aan deze spoorelementen te voorzien worden deze aan de meeste mengvoeders toegevoegd via de premix. Aangezien relatief weinig $\mathrm{Cu}$ en $\mathrm{Zn}$ door het dier wordt vastgelegd wordt het grootste deel van de opgenomen hoeveelheid weer uitgescheiden via de mest. $\mathrm{Bij}$ aanwending van de mest komen $\mathrm{Cu}$ en $\mathrm{Zn}$ in het milieu terecht. De belasting van de bodem met zware metalen is al geruime tijd een belangrijk aandachtspunt in het landbouw en milieubeleid. Naast meststoffen (kunstmest, compost, slib en zwarte grond) levert ook dierlijke mest een belangrijke bijdrage aan de belasting van de bodem met zware metalen (Hotsma et al., 1996; Westhoek et al., 1996). Met name de elementen $\mathrm{Cu}$ en $\mathrm{Zn}$ verdienen daarbij speciale aandacht. Mede vanwege milieuaspecten gelden wettelijke maxima voor $\mathrm{Cu}$ en $\mathrm{Zn}$ in veevoer. Voor pluimveevoeders is maximaal 25 mg/kg koper toegestaan. Voor Zn geldt sinds 27 juli 2016 (met een overgangstermijn) een maximum van $120 \mathrm{mg} / \mathrm{kg}$ voor alle pluimveevoeders (EU, 2003; EU, 2016).

De Nederlandse Voedsel- en Warenautoriteit (NVWA) heeft tot taak er op toe te zien dat de wettelijke normen niet worden overschreden. Dit zou bijvoorbeeld het geval kunnen zijn door het gebruik van $\mathrm{Cu}$ en/of $\mathrm{Zn}$-bevattende supplementen in voer en drinkwater naast het reeds aanwezige $\mathrm{Cu}$ en $\mathrm{Zn}$ in de gebruikte (meng)voeders. Dergelijke supplementen worden gebruikt voor ontsmetting en conditionering van het drinkwatersysteem maar ook ter ondersteuning van de bedrijfsvoering bij stresssituaties zoals entingen, voeroverschakelingen en tussentijds uitladen (afleveren) van dieren. Daarnaast wordt verondersteld dat koper en zink in een hogere dosering een groeibevorderend effect hebben. De wettelijke normen zijn van toepassing op het complete dagrantsoen (bij $88 \%$ drogestof), inclusief de eventuele verstrekking via supplementen in voer of drinkwater ${ }^{2}$. Analyse van $\mathrm{Cu}$ en $\mathrm{Zn}$ in het mengvoer alleen is dus niet voldoende om de totaal verstrekte hoeveelheid $\mathrm{Cu}$ en $\mathrm{Zn}$ te bepalen. De vraag in deze studie was daarom hoe gecontroleerd kan worden of de maximaal toegelaten gehalten aan $\mathrm{Cu}$ en $\mathrm{Zn}$ in de rantsoenen voor vleeskuikens zijn overschreden. De analyse van het aanwezige voer en drinkwater is daarbij uiteraard een goed hulpmiddel, maar dit is slechts een momentopname en geeft geen inzicht in eventuele overschrijding in de voorgaande periode. Daarom werd gezocht naar een andere, aanvullende benadering.

\section{$1.2 \quad$ Eerdere ervaring bij varkens}

Enige jaren geleden is, eveneens in opdracht van de NVWA, een methode beschreven waarmee bij varkens gecontroleerd kan worden of de toegelaten hoeveelheid $\mathrm{Cu}$ en $\mathrm{Zn}$ in het rantsoen wordt overschreden (Jongbloed et al., 2012). Met behulp van deze methode kon het gehalte aan $\mathrm{Cu}$ en $\mathrm{Zn}$ in het mengvoeder worden berekend op basis van het gemeten gehalte aan $\mathrm{Cu}$ en $\mathrm{Zn}$ in de feces en kwantitatieve informatie over de grondstoffensamenstelling van het mengvoeder. Hierbij zijn er wel een aantal variatiebronnen en onzekere of afgeleide factoren zoals de variatie in $\mathrm{Cu}$ - en $\mathrm{Zn}$-gehalten in de feces tussen dieren en hokken, de excretie van Cu en $\mathrm{Zn}$ via de urine welke in deze methode niet wordt bemonsterd, de vastlegging van $\mathrm{Cu}$ en $\mathrm{Zn}$ in het dier en de schatting van de verteringscoëfficiënt van de organische stof (OS) en de droge stof (DS) op basis van de CVBVeevoedertabel. In het betreffende rapport van Jongbloed et al. (2012) wordt de betrouwbaarheid van deze methodiek om op basis van het gehalte aan $\mathrm{Cu}$ en $\mathrm{Zn}$ in de feces een eventuele overschrijding van het $\mathrm{Cu}$ of $\mathrm{Zn}$-gehalte in het rantsoen vast te stellen, uiteengezet en daarnaast werden de

\footnotetext{
2 Conform Uitvoeringsverordening (EU) 2018/1039 is het toevoegen van supplementen met Cu aan drinkwater vanaf 13 augustus 2018, met een overgangsperiode tot 13 augustus 2019 voor bestaande voorraden, niet meer toegelaten.
} 
resultaten van een validerend onderzoek belicht. Inmiddels is deze methode sinds enige tijd met succes in de praktijk toegepast om een eventuele overschrijding van de periode of dosering van een groeibevorderende hoeveelheid $\mathrm{Cu}(170 \mathrm{mg} / \mathrm{kg}$ tot 12 weken leeftijd) vast te stellen.

\subsection{Methode voor vleeskuikens}

De vraag in deze studie was na te gaan of naar analogie van de methode voor vleesvarkens het Cu en Zn-gehalte in het rantsoen van vleeskuikens gecontroleerd kan worden op basis van het gehalte in de excreta. In deze rapportage wordt hiervoor een methode beschreven en besproken welke onzekerheden deze werkwijze met zich meebrengt. Van de opgenomen hoeveelheid $\mathrm{Cu}$ en $\mathrm{Zn}$ door het kuiken wordt doorgaans minder dan $10 \%$ in het dier vastgelegd. Het overgrote deel van de opgenomen $\mathrm{Cu}$ en $\mathrm{Zn}$ wordt dus weer uitgescheiden via de mest en urine. Bij pluimvee wordt de urine als een vaste laag (film) om de keutel uitgescheiden. In tegenstelling tot zoogdieren worden mest en urine dus niet apart uitgescheiden. Aangezien het merendeel van de Cu en $\mathrm{Zn}$ weer wordt uitgescheiden via de mest zou het gehalte aan deze spoorelementen in de mest een goede parameter kunnen zijn voor de opgenomen hoeveelheid met het rantsoen. Aangezien het wettelijk verplicht is vleeskuikens te huisvesten op strooisel (Besluit houders van dieren, 2014) en deze dieren vrij kunnen rondlopen in de stal is echter het niet eenvoudig om een schoon 'vers' mestmonster bij vleeskuikens te verzamelen. De mest die een vleeskuiken produceert valt niet op een schone vloer, maar op een vloer waarop een mengsel van strooisel en mest ligt, verder kortweg strooiselmest genoemd. Bij vleeskuikens kan een vers mestmonster eigenlijk alleen direct na het produceren worden genomen, omdat deze anders wordt vertrapt en vermengd met de reeds aanwezige strooiselmest. Maar ook dan is er een groot risico op vervuiling ervan door aanhechting van reeds aanwezige strooiselmest waarop de mest wordt uitgescheiden. Daarnaast is een vers mestmonster een momentopname, wat voor het beschreven doel wellicht minder gewenst is en weinig toevoegt aan het nemen van een monster van voer en drinkwater. Het verstrekken van supplementen gebeurt in de vleeskuikenhouderij vaak periodiek (bijv. bij stresssituaties zoals voeroverschakelingen of bij uitladen), waardoor een vers mestmonster geen representatief beeld geeft van de $\mathrm{Cu}$ en $\mathrm{Zn}$-opname in de voorgaande periode. Daarom is in deze studie een methode ontwikkeld om op basis van het Cu- en Zn-gehalte in een representatief monster van de strooiselmest het $\mathrm{Cu}$ en $\mathrm{Zn}$-gehalte van het rantsoen te schatten. Tevens zijn hierbij de meest relevante variatiebronnen en de mogelijke invloed hiervan beschreven.

In dit rapport wordt een methode beschreven om op basis van het gehalte aan $\mathrm{Cu}$ en $\mathrm{Zn}$ in strooiselmest bij vleeskuikens een inschatting te maken van de hoeveelheid $\mathrm{Cu}$ en $\mathrm{Zn}$ die via het voer en drinkwater is toegediend aan de dieren en om eventuele overschrijding van de normen te achterhalen. Daartoe volgt eerst een beknopte beschrijving van de houderij van vleeskuikens, de rol van $\mathrm{Cu}$ en $\mathrm{Zn}$ in het dier en de hoeveelheid $\mathrm{Cu}$ en $\mathrm{Zn}$ in het voer, dier en strooiselmest. Aansluitend wordt de ontwikkeling van de genoemde methode beschreven en vervolgens worden de resultaten vergeleken met gerealiseerde $\mathrm{Cu}$ en $\mathrm{Zn}$-gehalten op een aantal bedrijven met vleeskuikens. 


\section{$2 \quad$ Houderij van vleeskuikens}

In dit hoofdstuk wordt een beknopte beschrijving gegeven van de houderij van vleeskuikens, de rol van strooisel, de meest gebruikte strooiselmaterialen en de invloed hierop van de invoering van Europese welzijnswetgeving voor vleeskuikens.

\section{$2.1 \quad$ Algemeen}

Vleeskuikens worden meestal gehuisvest in dichte mechanisch geventileerde stallen. Een standaard vleeskuikenstal bestaat uit een grote, veelal rechthoekige ruimte met voeder- en drinklijnen in de lengterichting (Figuur 1). Het aantal voer- en drinklijnen in de stal is afhankelijk van de breedte van de stal. De maximale afstand tussen voer- en drinkpunt mag niet meer bedragen dan 3 meter. De kuikens verblijven in deze stal vanaf één dag tot ca. 6 weken leeftijd, waarna ze worden afgeleverd aan de slachterij. Aangezien eendagskuikens een grote warmtebehoefte hebben zijn vleeskuikenstallen vaak goed geïsoleerd. De dieren, die meestal gemengd worden opgezet d.w.z. hanen en hennen gezamenlijk, kunnen vrij rondlopen op betonnen vloeren waarop aan het begin van de productieronde een laag strooisel is aangebracht. Het verstrekken van strooisel aan vleeskuikens is wettelijk verplicht en is vastgelegd in de nationale regelgeving (Besluit houders van dieren, 2014; Vleeskuikenbesluit, 2010), waarin de Europese regelgeving (Richtlijn 2007/43/EG, 28 juni 2007 minimumvoorschriften voor de bescherming van vleeskuikens) is verwerkt. Met betrekking tot strooisel vermeldt het Vleeskuikenbesluit (2010): 'Alle vleeskuikens moeten permanent toegang hebben tot droog en los strooisel op de vloer'. Daarnaast wordt aangegeven dat alleen gesproken mag worden van 'bruikbare oppervlakte' indien een oppervlakte voorzien is van strooisel dat permanent voor de vleeskuikens toegankelijk is.
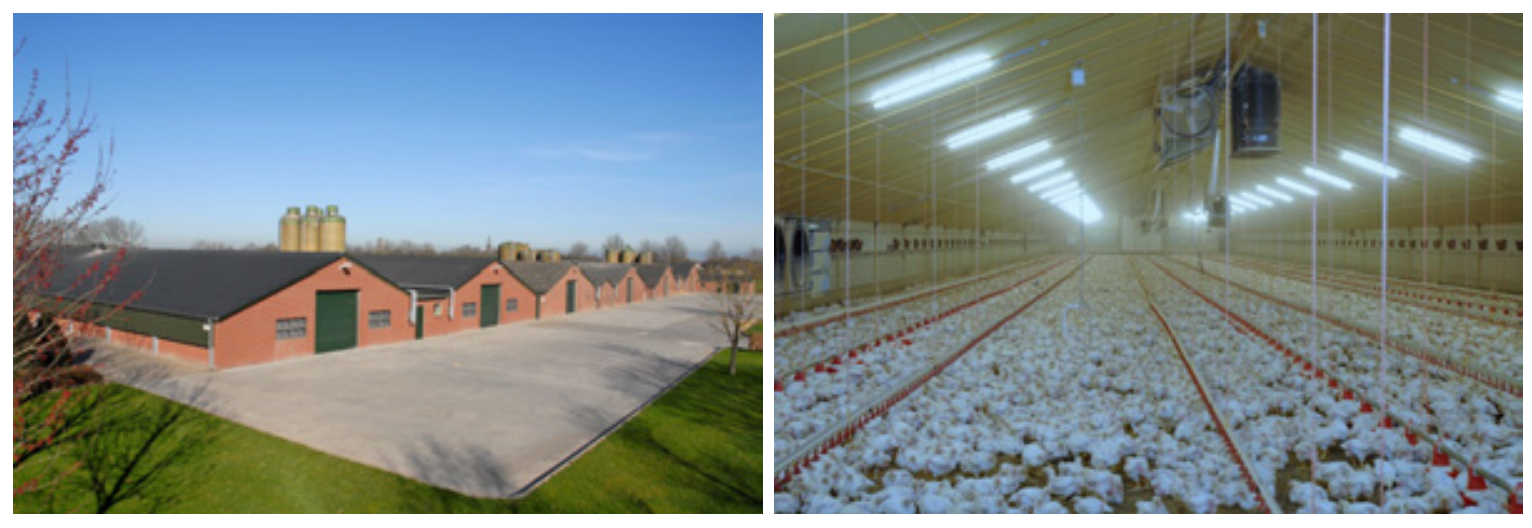

Figuur 1 Impressie van een modern vleeskuikenbedrijf (links) en de inrichting van een moderne vleeskuikenstal (rechts).

Zoals hierboven reeds aangegeven worden vleeskuikens gehouden op een betonnen vloer met hierop strooisel. Op deze vloer wordt ook de mest van kuikens wordt uitgescheiden. De hoeveelheid mest en de dikte van de strooisellaag neemt dus toe met het ouder worden van de kuikens. De mest blijft in de stal liggen tot de kuikens worden afgeleverd aan de slachterij, waarna de mest uit de stal wordt verwijderd en de stal wordt schoongemaakt en ontsmet. Het (grondig) reinigen en ontsmetten van de stal na iedere koppel is wettelijk voorgeschreven. In regelgeving is vastgelegd dat 'Delen van gebouwen, uitrusting of gereedschap die met de vleeskuikens in contact komen, moeten na elke definitieve ontruiming grondig worden gereinigd en ontsmet voordat nieuwe dieren in de stal worden binnengebracht. Na de definitieve ontruiming van een stal moet al het strooisel worden verwijderd en moet er vers strooisel worden aangebracht.' (Richtlijn 2007/43/EG). 


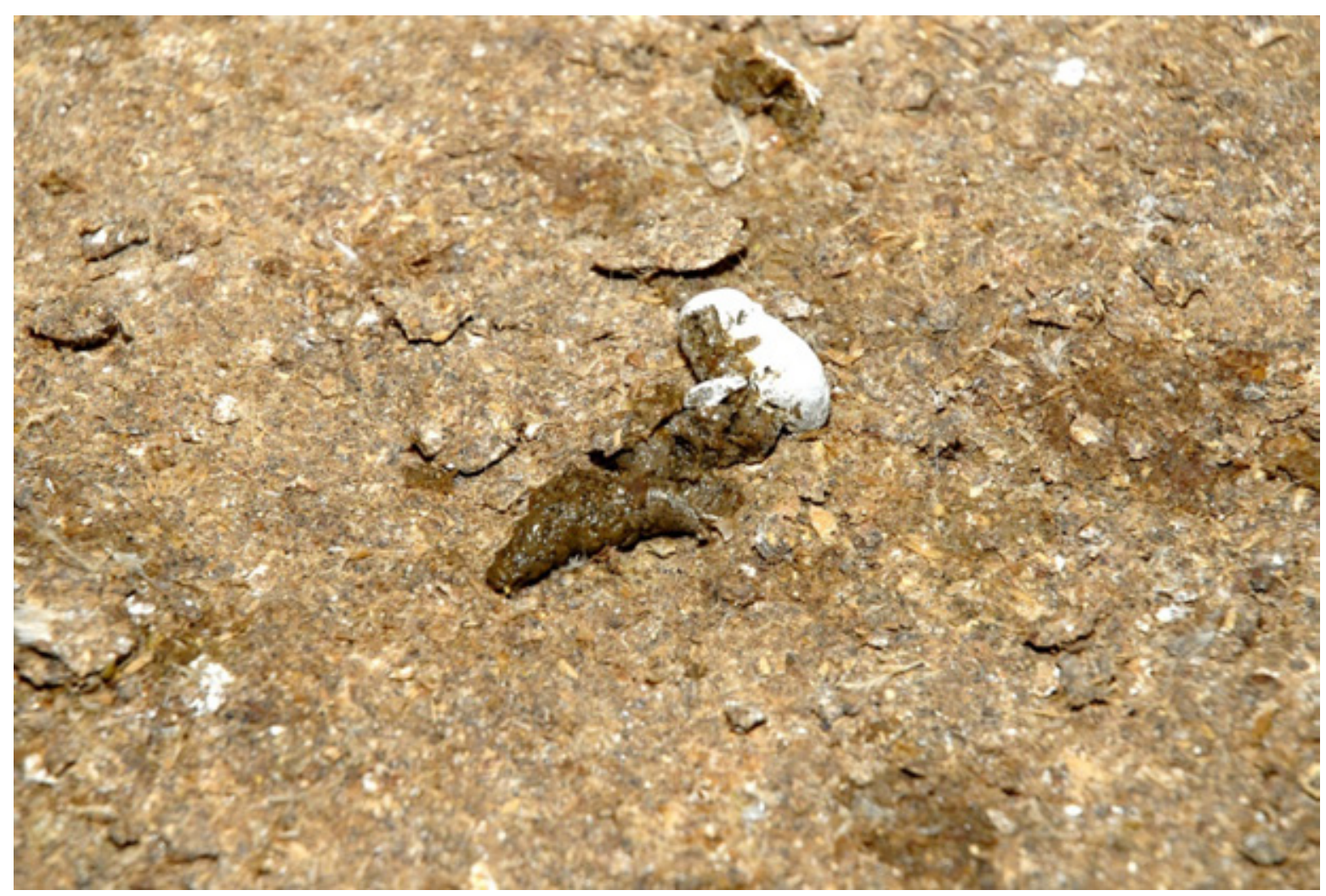

Figuur 2 Mest van vleeskuikens.

De uitwerpselen (excreta) van kuikens bestaat uit mest en urine (Figuur 2). De urine is in tegenstelling tot bijvoorbeeld varkens niet vloeibaar maar zit als een witte laag om de mest.

Sinds begin 2011 heeft de reguliere vleeskuikenhouderij te maken met de regels van het zogenoemde Vleeskuikenbesluit. In dit Vleeskuikenbesluit zijn regels voor de huisvesting van vleeskuikens vastgelegd, gebaseerd op de Europese welzijnsrichtlijn (Richtlijn 2007/43/EG). Deze richtlijn gaat uit van een maximum bezetting in vleeskuikenstallen van $33 \mathrm{~kg}$ levend gewicht per vierkante meter. Als vleeskuikenhouders voldoen aan extra eisen op het gebied van huisvesting, vakmanschap, uitval, e.d. kan deze bovengrens omhoog naar $39 \mathrm{~kg} / \mathrm{m}^{2}$ of, maximaal, $42 \mathrm{~kg} / \mathrm{m}^{2}$. Om bij de hoogste bezetting van $42 \mathrm{~kg} / \mathrm{m}^{2}$ te mogen produceren moet er voldaan worden aan extra eisen ten aanzien van uitval en incidentie van voetzoollaesies (Bijlagen 1 en 2 ). Voetzoollaesies zijn aantastingen van de opperhuid van de voetzool van vleeskuikens en deze worden veroorzaakt door nat en plakkerig strooisel. Om het aantal en de ernst van voetzoollaesies tot een minimum te beperken is het zaak de strooiselkwaliteit zo goed (d.w.z. droog) mogelijk te houden. Een vleeskuikenhouder heeft hiertoe een aantal managementmaatregelen in handen, welke hij kan gebruiken om te voorkomen dat het strooisel nat wordt en de incidentie van voetzoollaesies toeneemt. Het ontstaan van nat strooisel kan verschillende oorzaken hebben (slechte temperatuurverdeling, slechte lichtverdeling, onvoldoende ventilatie, drinkwatervermorsing, etc.). Ook een slechte darmgezondheid kan een reden zijn. Een van de maatregelen die een vleeskuikenhouder kan nemen om de darmgezondheid te waarborgen is het gebruik van een drinkwaterwateradditief of -supplement. Een andere reden van het toegenomen gebruik van drinkwateradditieven is de afspraak die de overheid en de verschillende diersectoren gemaakt hebben om het antibioticagebruik in de diersectoren te verminderen. De afspraken tussen de overheid en de verschillende diersectoren zijn vastgelegd in het convenant antibioticaresistentie dierhouderij van 8 december 2008 en hebben tot doel antibioticaresistentie te voorkomen. Voor de vleeskuikenhouderij was het streven in 2013 het gebruik van antibiotica met 50\% en in 2015 met $70 \%$ te hebben teruggebracht ten opzichte van het referentiejaar 2009. 


\subsection{Stalbroed - het laten uitkomen van kuikens in de stal}

Een van de recente innovaties in de Nederlandse vleeskuikensector is het laten uitkomen van de kuikens in de stal. Traditioneel worden eendagskuikens aangeleverd op het vleeskuikenbedrijf. Deze kuikens zijn uitgebroed op de broederij. In de broederij liggen broedeieren gedurende 18 dagen in een voorbroedkast om te worden bebroed. Daarna gaan de eieren 3 dagen in een uitkomstkast waar de kuikens uitkomen. De kuikens komen niet allemaal tegelijkertijd uit het ei, de eerste kuikens komen na circa 19 dagen uit het ei, de laatste na 20,5 dag. Na 21 dagen worden de kuikens uit de broedmachine gehaald (=afgeraapt), geselecteerd, in kratjes gedaan, eventueel gevaccineerd waarna ze op transport naar het vleeskuikenbedrijf gaan. Er zijn tegenwoordig ook bedrijven die geen eendagskuikens, maar 18-daags bebroede eieren laten aanvoeren en in de stal de kuikens laten uitkomen. Het laten uitkomen van kuikens in de stal is niet nieuw. In het patiosysteem (een (etage)systeem waarbij vleeskuikens in meerdere lagen boven elkaar worden gehuisvest) is dit namelijk gebruikelijk. Het overgrote deel van de Nederlandse vleeskuikens wordt echter gehuisvest in grondstallen. Met de komst van een aantal systemen zoals x-treck, home-hatching en One2Born behoort het laten uitkomen van kuikens in traditionele grondstallen ook tot de mogelijkheden (Figuur 3). De mogelijke voordelen van het uitkomen in de stal zijn dat (Lourens, 2009):

- de pas uitgekomen kuikens direct en naar behoefte voer en water kunnen opnemen en hierdoor geen water- en voeronthouding kennen;

- kuikens direct soorteigen gedrag kunnen gaan vertonen, mede omdat ze meteen de beschikking hebben over strooisel;

- de kuikens geen stress als gevolg van handelingen op de broederij meemaken;

- de kuikens geen transportstress van broederij naar de stal kennen;

- er geen stress optreedt als gevolg van hanteren en plaatsen in een nieuwe omgeving in de stal bij de vleeskuikenhouder.

Directe voer- en watertoegang stimuleren de orgaanontwikkeling en het immuunsysteem en zorgen daardoor voor robuuste kuikens en mogelijk lagere sterfte (Van de Ven et al., 2009). Nadat de kuikens zijn uitgekomen in de stal worden de niet uitgekomen eieren en eierschalen afgevoerd van het bedrijf. Een klein gedeelte van de eierschalen kan achterblijven in het strooisel in de stal. Het is niet de verwachting dat het laten uitkomen van kuikens enige invloed heeft op de koper- en zinkgehalte van strooiselmest. Wel zijn er aanwijzingen dat de strooiselmest droger is bij uitkomen van broedeieren in de stal, door een betere mestconsistentie van de dieren. Recent onderzoek van het Belgische "Proefbedrijf Pluimveehouderij" in Geel en Wageningen Universiteit \& Research naar de effecten van het laten uitkomen in de stal toonde aan de kuikens die in de stal uitkwamen efficiënter groeiden, en dat ook diergezondheid en dierenwelzijn positief werden beïnvloed. Kuikens die in de stal waren uitgekomen hadden een minder stressvolle start, waren zeer rustig en piepten nauwelijks. In vergelijking met kuikens die werden aangevoerd van een broederij ondergaan kuikens die in de stal uitkomen minder handelingen, hoeven niet op transport en hebben direct water en voer tot hun beschikking. Daarnaast was de strooiselkwaliteit bij de kuikens die in de stal waren uitgekomen beter (droger), waardoor er minder problemen aan de poten voorkwamen (voetzoollaesies).
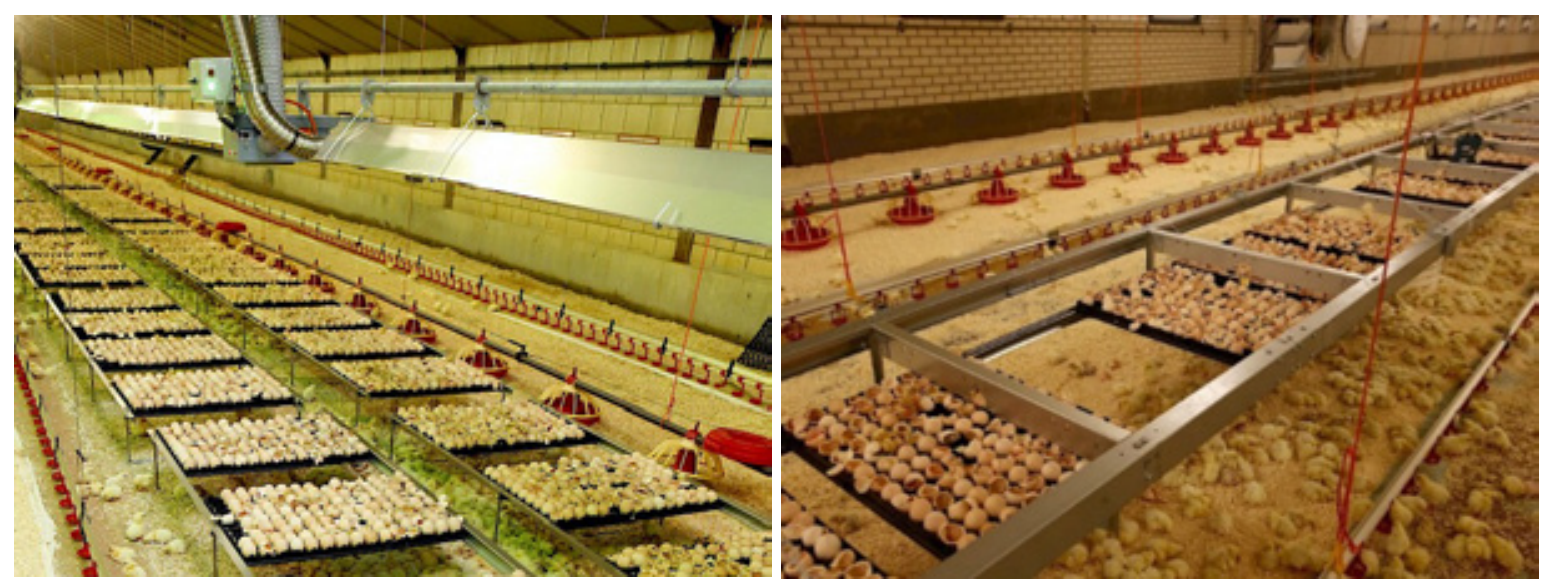

Figuur 3 Het laten uitkomen van kuiken in de stal. Links: home hatching systeem. Rechts: X-treck systeem. 


\subsection{Strooisel}

Zoals eerder vermeld dienen vleeskuikens te worden gehouden op strooisel. Houtkrullen en (gehakseld) tarwestro worden in Nederland het meest gebruik als strooiselmateriaal in vleeskuikenstallen. Vooral in akkerbouwgebieden wordt veel tarwestro gebruikt, daarbuiten meestal (witte) houtkrullen. Tarwestro wordt vrijwel altijd gehakseld. Reden hiervoor is dat gehakseld tarwestro meer vocht opneemt in vergelijking met ongehakseld tarwestro. Daarnaast is bij gebruik van relatief lange stengels moeilijk een egaal bed aan te brengen, waardoor het lastig is voor met name jonge kuikens zich hierop voort te bewegen. Mede hierdoor kan het gebruik van lang (ongehakseld) strooisel nadelige gevolgen hebben op de uniformiteit en het uiteindelijke (financiële) resultaat van een koppel. De belangrijke functies van strooisel zijn:

- Het absorberen van vocht

- Het verdunnen van excreta (mest), waardoor de kans op direct contact tussen dier en mest sterk vermindert

- Het bieden van isolatie (koude vloer)

- Het bieden van mogelijkheden tot het uitoefenen van specifieke gedragingen (bijv. stofbaden).

Goed strooisel kan omschreven worden als een materiaal dat veel vocht opneemt, het moet zacht en los zijn, het mag niet gemakkelijk samenklitten of een korst vormen, het moet goedkoop zijn en ruim beschikbaar. Daarnaast moet het strooisel 'schoon' zijn, d.w.z. vrij van schadelijke stoffen (pesticiden, toxische stoffen, e.d.). Houtkrullen is een geschikt strooiselmateriaal dat veel vocht opneemt, ruim beschikbaar en relatief goedkoop is. De laatste paar jaar is er een toename van het gebruik van hout(afval) als brandstof waardoor de markt voor houtkrullen- en houtvezels onder druk staat en de prijs van houtkrullen is toegenomen. Een andere ontwikkeling is de implementatie van EU welzijnswetgeving waarin eisen worden gesteld aan de maximale stalbezetting. Indien een vleeskuikenhouder kan voldoen aan bepaalde eisen dan mag een maximale bezetting van $42 \mathrm{~kg}$ per vierkante meter gehanteerd worden (zie 3.1 en Bijlage 1). De hogere prijs van de houtkrullen en de implementatie van de EU-welzijnswetgeving heeft niet alleen geleid tot een verschuiving van de gebruikte strooiselmaterialen in de vleeskuikenhouderij, maar ook tot het gebruik van andere strooiselmaterialen zoals turf en kokosstrooisel. Voorbeelden van strooiselmaterialen die gebruikt worden in de vleeskuikenhouderij zijn:

- Houtkrullen

- Zaagsel (hout)

- Tarwestro

- Gerstestro

- Haverstro

- Vlaslemen

- Turfstrooisel

- Kokosstro

- Koolzaadstro

- Snijmaissilage

Het strooisel wordt kort voor plaatsing van de kuikens in de stal ingebracht. De hoeveelheid strooisel die wordt gebruikt varieert en bedraagt gemiddeld $1 \mathrm{~kg} / \mathrm{m}^{2}$ vloeroppervlak (KWIN-V 2017-2018). Op dit strooisel produceert het kuiken zijn uitwerpselen. Het strooisel waarop de kuikens lopen is dus in feite een combinatie van strooiselmateriaal en uitwerpselen van het dier. Eigenlijk is het dus beter te spreken van strooiselmest, maar strooisel is in de sector een gangbaarder term. In het begin van de productieperiode is er dus relatief veel strooiselmateriaal en weinig mest, naarmate de productieperiode vordert neemt het aandeel mest toe. Na het afleveren van de kuikens aan de slachterij wordt de strooiselmest verwijderd uit de stal en wordt deze grondig (nat) gereinigd en ontsmet, waarna deze weer wordt klaargemaakt voor de ontvangst van de volgende koppel kuikens. 


\section{$3 \quad$ Koper en zink in de voeding}

In dit hoofdstuk wordt ingegaan op de rol van $\mathrm{Cu}$ en $\mathrm{Zn}$ in het dier en de (wettelijk) maximale gehalten aan $\mathrm{Cu}$ en $\mathrm{Zn}$ in het rantsoen.

\subsection{Rol van koper en zink in het dier}

Koper en zink zijn beide essentiële spoorelementen en spelen als component in een groot aantal metallo(metaal)enzymen een belangrijke rol in de stofwisseling van dieren; een tekort leidt tot gezondheidsproblemen en tot lagere dierprestaties. Regulering van de absorptie van koper en zink door de darmcellen is een ingewikkeld proces dat afhankelijk is van veel factoren die met het voer (o.a. het voorzieningsniveau, aanwezigheid andere mineralen) en met het dier te maken hebben. Het transport van koper en zink door de darmcel gebeurt deels via gemeenschappelijke processen, zodat er een sterke wederzijdse beïnvloeding van deze elementen bestaat.

Koper speelt een essentiële rol bij diverse stofwisselingsprocessen in het dier (McDowell, 1992). Koper heeft een duidelijke invloed op eetlust en voerefficiëntie en afgeleid daarvan op de groei. Koper is onder meer betrokken bij de bloedvorming, nodig voor celademhaling, de vorming van collageen in de botmatrix, ontwikkeling van bindweefsel, pigmentvorming, hartfunctie, reproductie, immuunsysteem, vetstofwisseling, bij de vorming van myelinescheden rond zenuwuitlopers en keratinevorming. Een tekort aan koper kan botafwijkingen veroorzaken. Tibiale dyschondroplasia is hier een voorbeeld van. Daarnaast kan een koper tekort ook leiden tot bloedarmoede, cardiovasculaire laesies, aorta rupturen (kalkoenen), verlamming, veerafwijkingen en verminderde groei (Leeson, 2009).

Evenals koper is zink essentieel in veel stofwisselingsprocessen (McDowell, 1992). Het heeft een duidelijke invloed op eetlust en voerefficiëntie en afgeleid daarvan op de groei. Zink is onderdeel van verschillende enzymen en betrokken bij de transcriptie van DNA. Zo is zink onderdeel van de enzymen carbonzuur anhydrase, alkalische fosfatase en alcohol dehydrogenase. Zink is o.a. betrokken bij de eiwitsynthese, koolhydraat- en nucleinezuurstofwisseling. Ook heeft zink veel biologische interacties met hormonen (testosteron, insuline en corticosteroïden). Zink is essentieel voor een goed functionerend immuunsysteem, water- en kationbalans, huid en wondheling en het handhaven van normale concentraties aan vitamine A. Een zinkgebrek kan leiden tot een groeivertraging, verhoging van de voederconversie, hakvergrotingen (dikke hakken), verkorting en verdikking van de lange botten en slechte/gekroesde bevedering (Nielsen, 2012).

\subsection{Koper- en zinkbehoefte van vleeskuikens}

In Tabel 1 worden voor Cu en $\mathrm{Zn}$ de maximaal toegelaten gehalten in het rantsoen binnen de EU en de behoefte van vleeskuikens volgens de National Research Council (1994) en GfE (1999) weergegeven.

Tabel 1 Maximaal toegelaten koper- en zinkgehalte in vleeskuikenvoer (EU verordening 1334/2003) en fysiologische koper- en zinkbehoefte van vleeskuikens volgens NRC (1994) en GfE (2004).

\begin{tabular}{lccc} 
Max, toegestaan & $\begin{array}{c}\text { Behoefte NRC } \\
(\mathrm{mg} / \mathrm{kg})\end{array}$ & 8 & $\begin{array}{c}\text { Behoefte GfE } \\
(\mathrm{mg} / \mathrm{kg} \mathrm{DS})^{4}\end{array}$ \\
Koper & $25^{1}$ & 40 & 7 \\
\hline Zink & $120^{2}$ & 50 \\
\hline
\end{tabular}

1 EU verordening 1334/2003; ${ }^{2}$ Uitvoeringsverordening (EU) 2016/1095; ${ }^{3}$ National Research Council, $1994 ;{ }^{4}$ GfE, Duitsland, 1999. 
In Nederland zijn drie fokkerijgroeperingen op de vleeskuikenmarkt actief. In Tabel 2 worden de adviezen voor $\mathrm{Cu}$ en $\mathrm{Zn}$ van deze fokkerijgroeperingen voor hun fokproducten vermeld. Vrijwel alle fokkers adviseren om aan mengvoer twee keer zoveel $\mathrm{Cu}$ en $\mathrm{Zn}$ toe te voegen als de fysiologische behoefte van het dier.

Tabel 2 Door fokkers geadviseerde supplementair Cu en $\mathrm{Zn}$ aan vleeskuikenvoeders.

\begin{tabular}{lcccc} 
& Aviagen $^{1}$ & Cobb Vantress ${ }^{2}$ & Hubbard $^{3}$ \\
Koper $(\mathrm{mg} / \mathrm{kg})$ & 16 & 15 & 10 \\
\hline Zink $(\mathrm{mg} / \mathrm{kg}$ & 100 & 100 & 80 \\
\hline
\end{tabular}

1 Ross 308 (2014); ${ }^{2}$ Cobb 500 (2015); ${ }^{3}$ Hubbard Flex, (2015).

\subsection{Maximale gehalten aan koper en zink}

In de EG verordening 1334/2003 van 25 juli 2003 tot wijziging van de toelatingsvoorwaarden voor een aantal toevoegingsmiddelen van de groep sporenelementen in diervoeders is opgenomen dat het maximumgehalte van koper en zink in een volledig diervoeder respectievelijk 25 en $150 \mathrm{mg} / \mathrm{kg}$ mogen bedragen. Op 6 juli 2016 is echter bepaald dat per 27 juli 2016 (met een overgangstermijn) het maximum zinkgehalte in vleeskuikenvoeders $120 \mathrm{mg} / \mathrm{kg}$ mag bedragen (Uitvoeringsverordening (EU) 2016/1095). Het is opmerkelijk dat er geen eisen worden gesteld aan de hoeveelheden $\mathrm{Cu}$ en $\mathrm{Zn}$ via een supplement aan het drinkwater worden toegevoegd (drinkwaterwateradditief). In de wetgeving worden supplementen in drinkwater als onderdeel van het rantsoen gezien. De dosering dient dus samen met die uit mengvoer en eventuele losse grondstoffen als tarwe binnen de rantsoennorm te blijven. In de praktijk lijkt dit soms tot verwarring te leiden.

\subsection{Bronnen van koper en zink in het voer}

Koper en zink in het voer zijn afkomstig uit de hierin verwerkte grondstoffen en uit het mineralenpremix. De hoeveelheid koper en zink die via de grondstoffen in de voeders komt, is in de praktijk nauwelijks te beïnvloeden, aangezien de grondstoffensamenstelling van de voeders primair op basis van het energie- en eiwit-/aminozurengehalte van de grondstoffen en de grondstofprijzen wordt bepaald. De hoeveelheid koper en zink afkomstig van de grondstoffen is respectievelijk 5-10 mg $\mathrm{Cu} / \mathrm{kg}$ voer en $30-40 \mathrm{mg} \mathrm{Zn/kg}$ voer. Aangezien de beschikbaarheid van koper en zink uit de grondstoffen niet goed bekend is en wordt beperkt door natuurlijke componenten als fytaat en vezels worden koper en zink via een mineralenpremix toegevoegd aan het voer om de koper- en zinkbehoefte van het dier te dekken. Koper wordt vaak als kopersulfaat $\left(\mathrm{CuSO}_{4} .5 \mathrm{H}_{2} \mathrm{O}\right)$ toegevoegd, terwijl zink als zinksulfaat $\left(\mathrm{ZnSO}_{4} .7 \mathrm{H}_{2} \mathrm{O}\right)$ of zinkoxide $(\mathrm{ZnO})$ wordt toegevoegd. Daarnaast worden koper en zink ook in organische vorm (chelaten) toegevoegd.

De beschikbaarheid van koper en zink vanuit de grondstoffen kan vergroot worden door het gebruik van (microbieel) fytase, een enzym dat de fosforverteerbaarheid verbetert doordat het fytaatfosfor (dit is voor een kip slecht verteerbaar) vrij maakt voor het dier. Door gebruik van fytase hoeft er minder fosfor in het voer te worden opgenomen, waardoor de fosforexcretie ook lager is. Het enzym fytase wordt in Nederland op grote schaal in vleeskuikenvoeders gebruikt.

De hoeveelheid koper en zink die aan het voer wordt toegevoegd via een premix is variabel, maar meestal wordt er zoveel toegevoegd dat alleen al via de premix in de behoefte van de dieren kan worden voorzien. Daarbij wordt vaak een zekere veiligheidsmarge aangehouden in verband met variatie in productiviteit, gezondheid en management. Nederlandse vleeskuikenvoeders bevatten in 2007 gemiddeld 25 mg/kg koper en 123 mg/kg zink (M.C. Blok, persoonlijke mededeling). Van de $25 \mathrm{mg} / \mathrm{kg}$ koper was $7 \mathrm{mg} / \mathrm{kg}$ afkomstig uit de grondstoffen en $18 \mathrm{mg} / \mathrm{kg}$ uit premix. Van de $123 \mathrm{mg} / \mathrm{kg}$ zink was $40 \mathrm{mg} / \mathrm{kg}$ afkomstig uit de grondstoffen en $83 \mathrm{mg} / \mathrm{kg}$ uit premix. 


\subsection{Koper en zink in praktijkvoeders}

In Tabel 3 worden per voerfase de toegevoegde hoeveelheden koper en zink vermeld. Deze informatie is afkomstig van voerbonnen van zes leveranciers van vleeskuikenvoeders. Uitgaande van een bijdrage aan koper en zink vanuit de grondstoffen van 5-10 mg Cu/kg voer en 30-40 mg Zn/kg voer blijven gemiddeld genomen de totale gehalten aan $\mathrm{Cu}$ en $\mathrm{Zn}$ beneden de maximaal toegestane hoeveelheden (voor koper en zink respectievelijk 25 en $150 \mathrm{mg} / \mathrm{kg}$ ), ook wanneer wordt uitgegaan van een maximale $\mathrm{Cu}$ en/of $\mathrm{Zn}$ bijdrage vanuit de grondstoffen (Tabel 4). In een enkel geval, als wordt uitgegaan van een bijdrage vanuit de grondstoffen van $10 \mathrm{mg} / \mathrm{kg} \mathrm{Cu}$ en $40 \mathrm{mg} / \mathrm{kg} \mathrm{Zn}$, wordt de maximale hoeveelheid overschreden. Of dit daadwerkelijk ook het geval is geweest is niet te zeggen, aangezien de voeders niet zijn geanalyseerd.

Tabel 3 Toegevoegd koper-en zink in vleeskuikenvoer per voerfase op basis van voerbon informatie van zes voerleveranciers (referentie: september - oktober 2016).

\begin{tabular}{llrrrrrr} 
& & \multicolumn{3}{c}{ Toegevoegd koper } & \multicolumn{3}{c}{ Toegevoegd zink } \\
Voerfase & Periode & Gem. & Min & Max & Gem. & Min & Max \\
\hline Pre-start & $0-7$ & $\mathbf{1 5}$ & 14 & 17 & $\mathbf{1 0 1}$ & $\mathbf{9 6}$ & 75 \\
\hline Start & $0-14$ & $\mathbf{1 5}$ & 14 & 15 & 17 & $\mathbf{9 9}$ & 76 \\
\hline Groei I & $10-21$ & $\mathbf{1 5}$ & 14 & 12 & 122 \\
\hline Groei II & $21-32$ & $\mathbf{1 4}$ & $\mathbf{1 4}$ & 12 & 16 & $\mathbf{9 6}$ & 62 \\
\hline Eind & $32-$ afl. & $\mathbf{8 9}$ & 68 & 122 \\
\hline
\end{tabular}

Op 6 juli 2016 heeft de Europese Commissie bepaald het maximumniveau zink in diervoeders te verlagen van $150 \mathrm{mg} / \mathrm{kg}$ naar $120 \mathrm{mg} / \mathrm{kg}$. Voor premixen is dit aangescherpte voorschrift ingegaan op 27-1-2017 en voor mengvoeders op 27-7-2017, zodat het mogelijk is de oude premixen in de tussentijd op te maken (Uitvoeringsverordening (EU) 2016/1095). Aangezien de bedrijfsbezoeken in de periode september - november 2016 hebben plaatsgevonden, dus in de overgangsperiode, was een totaal zinkgehalte van $150 \mathrm{mg} / \mathrm{kg}$ zink in het voer nog geoorloofd.

Tabel 4 Totale hoeveelheid koper- en zink in vleeskuikenvoer per voerfase op basis van de toegevoegde hoeveelheden $\mathrm{Cu}$ en $\mathrm{Zn}$ als vermeld op de voerbon bij een maximale bijdrage aan Cu en Zn vanuit de grondstoffen (periode: september - oktober 2016).

\begin{tabular}{llrrrrrr} 
& & \multicolumn{2}{c}{ Total koper } & \multicolumn{2}{c}{ Total zink } \\
Voerfase & Periode & Gem. & Min & Max & Gem. & Min & 120 \\
\hline Pre-start & $0-7$ & $\mathbf{2 5}$ & 24 & 27 & $\mathbf{1 4 1}$ & 160 \\
\hline Start & $0-14$ & $\mathbf{2 5}$ & 24 & 25 & $\mathbf{1 3 6}$ & 115 & 160 \\
\hline Groei I & $10-21$ & $\mathbf{2 5}$ & 24 & 27 & $\mathbf{1 3 9}$ & 116 \\
\hline Groei II & $21-32$ & $\mathbf{2 4}$ & 22 & 26 & $\mathbf{1 3 6}$ & 102 \\
\hline Eind & $32-$ afl. & $\mathbf{2 4}$ & 22 & 26 & $\mathbf{1 2 9}$ & 108 & 162 \\
\hline
\end{tabular}

\subsection{Bijdrage drinkwater supplementen aan de excretie}

Op de markt zijn vele drinkwatersupplementen verkrijgbaar. Sommige zijn bedoeld om de drinkwaterhygiëne te waarborgen, andere worden gebruikt als een (aanvullend) voedingsadditief of ondersteunen de darmgezondheid, het immuunsysteem en/of voorkomen en verminderen salmonella. Vanuit de oudheid is bekend dat koper een kiemdodende werking heeft. Zo beschrijft een Egyptische tekst op een papyrusrol, daterend van tussen 2600 en 2200 voor Christus, al hoe koper kan worden gebruikt voor de ontsmetting van wonden en het steriliseren van water [https://www.rd.nl/meerrd/gezondheid/koper-bestrijdt-bacterie-en-virus-in-ziekenhuis-1.640150]. Deze kiemdodende werking is een van de redenen waarom koper wordt toegevoegd aan drinkwatersupplementen. Hoeveel koper 
in deze producten zit wordt meestal niet vermeld. Op het productlabel staat vaak alleen maar dat er koper (E4) in zit, maar niet de hoeveelheid of dosis. Uiteraard staat wel de gewenste dosering van het additief op het label, veelal tussen 1 - 2 liter per 1000 liter drinkwater.

Zoals aangegeven bevatten niet alle drinkwatersupplementen koper en/of zink, maar de gehalten aan $\mathrm{Cu}$ en/of Zn kunnen behoorlijk hoog zijn. Het gebruik van deze supplementen kan dus een wezenlijke invloed hebben op de totale $\mathrm{Cu}$ en $\mathrm{Zn}$ voorziening en excretie. Om meer inzicht te krijgen in deze bijdrage is het gewenst te inventariseren welke drinkwateradditieven $\mathrm{Cu}$ en/of $\mathrm{Zn}$ bevatten en in welk gehalte, en welke bijdrage het wateradditief heeft aan de $\mathrm{Cu}$ en/of $\mathrm{Zn}$ opname van het dier bij de aanbevolen dosering van de leverancier. Aangezien niet bekend is hoeveel primaire bedrijven (vleeskuikenproductiebedrijven) drinkwatersupplementen gebruiken en hoeveel van deze koper en/of zink bevatten en in welke dosering is het niet goed mogelijk in te schatten hoeveel bedrijven de maximaal toelaatbare koper- en zinkgehalten overschrijden. Uit een veldstudie in 2010 waarbij werd gekeken naar de effecten van het gevoerde management op het bedrijf op het voorkomen van voetzoollaesies kwam naar voren dat 24 van 34 bezochte bedrijven (71\%) op enig moment een drinkwateradditief gebruikte (Persoonlijke mededeling Van Harn, 2015). In een meer recent onderzoek van Wageningen Livestock Research waarbij de effecten van emissiearme stalsystemen op het optreden van uitval en de voetzoollaesie-score bij vleeskuikens werd onderzocht bleek dat slechts 3 van de 30 bezochte vleeskuikenbedrijven nooit een drinkwateradditief gebruikten. Dit betekent dat $90 \%$ van de bedrijven op enig moment drinkwateradditieven of -supplementen gebruikt (Van Harn, e.a., 2015). Er werd in deze onderzoeken niet geregistreerd welke supplementen dit betrof, gedurende welke periode en in welke dosering.

Om meer inzicht te verkrijgen in de beschikbare koper- en/of zink bevattende

drinkwatersupplementen is op internet gezocht naar producten, waarna fabrikanten of leveranciers van deze producten zijn benaderd en gevraagd naar het gehalte aan koper en/of zink in hun producten, de adviesdosering en de geadviseerde periode en duur van verstrekking. In Bijlage 3 wordt een overzicht gegeven van een aantal drinkwateradditieven welke koper en/of zink bevatten, met daarbij de vorm en het gehalte aan koper en/of zink en de adviesdosering. Benadrukt wordt dat er waarschijnlijk meer drinkwatersupplementen op de markt voorhanden zijn dan er in dit overzicht vermeld staan. Het Cu- en Zn-gehalte van deze producten varieert van minder dan 100 tot meer dan $50000 \mathrm{mg} / \mathrm{L}$. Wanneer de supplementen conform advies worden verstrekt aan de dieren dan wordt het maximale koper- en/of zinkgehalte in het rantsoen niet overschreden door de bijdrage van de supplementen op zichzelf, maar wel in combinatie met de hoeveelheid Cu en $\mathrm{Zn}$ uit het voer. De vleeskuikenhouder dient hier dus alert op te zijn. De bijdrage van een wateradditief aan de totale $\mathrm{Cu}$ en $\mathrm{Zn}$ opname door het dier wordt hieronder door middel van twee willekeurige voorbeelden geïllustreerd.

\section{Voorbeeld 1}

Selko $\mathrm{pH}$ is een mengsel van vrije en hoog gebufferde organische zuren ter waarborging van de drinkwaterhygiëne. Selko pH bevat per kg 2100 mg koper en 600 mg Zn. De adviesdosering voor Selko $\mathrm{pH}$ is 1-2 liter per 1000 liter water. Indien dit product gedurende de gehele productieperiode ( 0 - 41 dagen) via het drinkwater aan de dieren wordt verstrekt dan neemt een dier via deze weg bij een dosering van $0,1 \%$ en $0,2 \%$ respectievelijk 14 en $27 \mathrm{mg}$ koper op (Tabel 5). Bij de aanname dat een vleeskuiken via het voer $92 \mathrm{mg}(3,69 \mathrm{~kg}$ voer $\times 25 \mathrm{mg} / \mathrm{kg})$ koper opneemt, dan is de hoeveelheid $\mathrm{Cu}$ die vanuit het water aan het rantsoen wordt bijgedragen bij een dosering van 0,1 en $0,2 \%$ Selko $\mathrm{pH}$ respectievelijk 16 en 28 procent. 
Tabel 5 Bijdrage van het drinkwatersupplement Selko pH aan koper en zink opname van een vleeskuiken bij permanente dosering van respectievelijk 0,1 en 0,2\% gedurende de gehele groeiperiode.

\begin{tabular}{|c|c|c|c|c|}
\hline & \multicolumn{2}{|c|}{$\begin{array}{c}\text { Selko } \mathrm{pH} \\
\text { (1L/1000L drinkwater) }\end{array}$} & \multicolumn{2}{|c|}{$\begin{array}{l}\text { Selko pH } \\
\text { (2L/1000Ldrinkwater) }\end{array}$} \\
\hline Gewicht $(g)^{1}$ & \multicolumn{2}{|c|}{2280} & \multicolumn{2}{|c|}{2280} \\
\hline Voerconversie ${ }^{1}$ & \multicolumn{2}{|c|}{1,63} & \multicolumn{2}{|c|}{1,63} \\
\hline Voeropname $(\mathrm{g})^{1}$ & \multicolumn{2}{|c|}{3716} & \multicolumn{2}{|c|}{3716} \\
\hline Water/voer & \multicolumn{2}{|c|}{1,75} & \multicolumn{2}{|c|}{1,75} \\
\hline \multirow[t]{2}{*}{ Water (ml) } & \multicolumn{2}{|c|}{6503} & \multicolumn{2}{|c|}{6503} \\
\hline & Koper (mg) & Zink (mg) & Koper (mg) & Zink (mg) \\
\hline Bijdrage via drinkwater & 14 & 4 & 27 & 8 \\
\hline Bijdrage via voer & 93 & 446 & 93 & 446 \\
\hline Totaal water + voer & 107 & 450 & 120 & 454 \\
\hline In rantsoen, in $\mathrm{mg} / \mathrm{kg}$ voer & $29(115 \%)$ & $121(101 \%)$ & $32(129 \%)$ & $122(102 \%)$ \\
\hline
\end{tabular}

1 KWIN-V 2017-2018.

Hierbij dient te worden opgemerkt dat een drinkwatersupplement zelden gedurende de gehele productieperiode wordt verstrekt. Veelal is de periode van toepassing 30 tot $50 \%$ van de gehele groeiperiode.

\section{Voorbeeld 2}

Intracare Nutrimix is een drinkwatersupplement bedoeld ter ondersteuning van de bedrijfsvoering bij stresssituatie (bijv. voeroverschakelingen, tussentijds uitladen, vaccinaties, e.d.) en om het medicijnverbruik terug te dringen. Nutrimix bevat $14 \mathrm{~g}$ koper en $25 \mathrm{~g}$ zink per liter product. De adviesdosering is 1 liter per 1000 liter drinkwater. Geadviseerd wordt dit product van dag 1-5, van dag 17 - 21 en van $37-41$ te gebruiken. Dit is 15 dagen en uitgaande van een gemiddelde wateropname van $158 \mathrm{ml}$ per dag komt dit neer op 15 dagen $\times 158 \mathrm{ml} / \mathrm{dag} \times 14 \mathrm{mg} \mathrm{Cu} / 1000 \mathrm{ml}=$ $33 \mathrm{mg}$ Cu en 15 dagen $\times 158 \mathrm{ml} / \mathrm{dag} \times 25 \mathrm{mg} \mathrm{Zn/1000} \mathrm{ml} \mathrm{=} 59 \mathrm{mg} \mathrm{Zn}$ (Tabel 6). Ervan uitgaande dat het voer de maximaal toegestane hoeveelheid koper en zink bevat (resp. $25 \mathrm{mg} / \mathrm{kg}$ Cu en 120 mg/kg Zn) dan neemt een kuiken via het voer ca. 92 mg koper en 446 mg zink op. Wordt hiernaast nog eens het voedingssupplement Nutrimix volgens voorschrift verstrekt dan wordt via dit supplement nog eens $33 \mathrm{mg}$ koper (+36\%) en $59 \mathrm{mg}(+11 \%)$ zink extra verstrekt via het water.

Tabel 6 Bijdrage van het drinkwatersupplement Intracare Nutrimix aan koper en zink opname vleeskuikens bij de adviesdosering (0,1\% gedurende 15 dagen: van dag 0-5, 17-21 en 37 - 41).

\begin{tabular}{|c|c|c|}
\hline & \multicolumn{2}{|c|}{ Intracare Nutrimix } \\
\hline Voerconversie $^{1}$ & \multicolumn{2}{|c|}{1,63} \\
\hline Water/voer & \multicolumn{2}{|c|}{1,75} \\
\hline Water (ml) & \multicolumn{2}{|c|}{6503} \\
\hline Bijdrage via drinkwater & 33 & 59 \\
\hline Bijdrage via voer & 93 & 446 \\
\hline Totaal water + voer & 126 & 505 \\
\hline In rantsoen, in $\mathrm{mg} / \mathrm{kg}$ voer & $34(136 \%)$ & $136(113 \%)$ \\
\hline
\end{tabular}

1 KWIN-V 2017-2018 voor het gehele groeitraject

Uit bovenstaande twee voorbeelden blijkt dat de bijdrage aan $\mathrm{Cu}$ en $\mathrm{Zn}$ via drinkwatersupplementen kan resulteren in een overschrijding van de wettelijk toegelaten gehalten in het rantsoen en bijdraagt aan de excretie van $\mathrm{Cu}$ en $\mathrm{Zn}$ in het milieu. 


\section{$4 \quad$ Ontwikkeling van de methodiek}

\subsection{Algemene beschrijving en aanpak}

Het was de bedoeling van deze studie een methode te ontwikkelen waarmee op basis van de excretie in de mest het gehalte aan $\mathrm{Cu}$ en $\mathrm{Zn}$ in het rantsoen (voer en drinkwater) van vleeskuikens kan worden ingeschat. Omdat het moeilijk is schone verse mest te verzamelen en omdat supplementen veelal slechts in specifieke perioden worden verstrekt is een methode ontwikkeld op basis van bemonstering van strooiselmest. Op basis hiervan kan een inschatting worden gemaakt van het gemiddelde $\mathrm{Cu}$ en $\mathrm{Zn}$-gehalte in het rantsoen in de gehele voorgaande periode tussen opleggen van de kuikens en het moment van monstername. In dit hoofdstuk wordt het principe van de methode beschreven, een gevoeligheidsanalyse uitgevoerd en een beknopte validatie aan de hand van proefgegevens gepresenteerd.

De methode is gebaseerd op het gehalte aan Cu en $\mathrm{Zn}$ ten opzichte van de drogestof (DS) in het voer enerzijds en in de excreta anderzijds. De verteerbaarheid van de DS van een vleeskuikenvoer bedraagt gemiddeld circa $70-75 \%$. Omdat van $\mathrm{Cu}$ en $\mathrm{Zn}$ in het voer slechts een zeer beperkt aandeel (minder dan 10\%) wordt opgenomen en vastgelegd is het gehalte in de DS van de mest veel hoger dan in het voer. Wanneer in het geheel geen $\mathrm{Cu}$ en $\mathrm{Zn}$ wordt vastgelegd kan het aandeel in het voer berekend worden met de DS-verteringscoëfficiënt (VCDS) van het voer als:

$$
\mathrm{Cu} \text { in DS-voer }=100 \times \mathrm{Cu} \text { in DS-mest } /(100-\mathrm{VCDS})
$$

In paragraaf 4.2 wordt ingegaan op de bepaling van de VCDS van het voer. In werkelijkheid wordt een klein deel van het $\mathrm{Cu}$ en $\mathrm{Zn}$ uit voer vastgelegd in het dier zodat geldt:

$\mathrm{Cu}$ in DS-voer $=100 \times \mathrm{Cu}$ in DS-mest $/(100-\mathrm{VCDS})+\mathrm{Cu}$-retentie in dier

De Cu- en Zn-retentie in het dier kunnen worden gebaseerd op het gehalte in het lichaam van de vleeskuikens. Dit wordt in paragraaf 4.3 nader uitgewerkt. Daarnaast moet deze retentie per $\mathrm{kg}$ lichaamsgewicht gerelateerd kunnen worden aan de DS-opname van de vleeskuikens. Hiervoor is kennis nodig van de voederconversie ofwel de voeropname en groei van de kuikens.

De berekening zoals hier beschreven is gebaseerd op de excreta van het dier, terwijl de strooiselmest ook DS, Cu en Zn vanuit het strooiselmateriaal bevat. De DS uit strooiselmateriaal heeft een verdunnend (verlagend) effect op het $\mathrm{Cu}$ en $\mathrm{Zn}$-gehalte terwijl anderzijds de bijdrage $\mathrm{Cu}$ en $\mathrm{Zn}$ uit het strooisel een verhogend effect heeft op het gehalte hiervan in strooiselmest. Om hiervoor te corrigeren is kennis van de samenstelling van het strooiselmateriaal nodig en inzicht in het relatieve aandeel DS uit strooiselmateriaal in de strooiselmest. Dit laatste vereist kennis van de gebruikte hoeveelheid schoon strooiselmateriaal en de excretie van DS door de vleeskuikens per eenheid $\left(\mathrm{m}^{2}\right)$ staloppervlakte. De DS-excretie kan worden berekend op basis van het aantal opgelegde dieren per $\mathrm{m}^{2}$, de uitval, en hiervoor reeds genoemde gegevens met betrekking tot (cumulatieve) voeropname en DS-verteerbaarheid van het voer.

Met deze systematiek kan uit analyse van het DS-, Cu- en Zn-gehalte van strooiselmest op elk moment in de groeiperiode het gemiddeld $\mathrm{Cu}$ - en $\mathrm{Zn}$-gehalte van het rantsoen worden berekend. Deze aanpak is uitgewerkt in een spreadsheetmodel in Excel. Hiervoor waren aannames nodig met betrekking tot de volgende kenmerken:

- De DS-verteerbaarheid van het rantsoen

- De vastlegging van Cu en $\mathrm{Zn}$ in de vleeskuikens

- De groeiprestaties van de dieren en de bezettingsdichtheid

- Samenstelling en gebruik van strooiselmateriaal 
In de volgende paragrafen worden deze punten achtereenvolgens uitgewerkt. Hierbij wordt eerst de aanpak beschreven die is gevolgd om de benodigde informatie te achterhalen en worden aansluitend de resultaten hiervan besproken. Aansluitend wordt in paragraaf 4.6 een gevoeligheidsanalyse uitgevoerd om de invloed van variatie in een aantal inputfactoren te simuleren.

In Hoofdstuk 5 wordt nader ingegaan op de mestsamenstelling

\subsection{Drogestof verteerbaarheid van het voer}

\subsubsection{Methode}

De DS-verteerbaarheid van het voer is een belangrijke factor omdat bij een lagere verteerbaarheid van de droge stof meer droge stof met de mest uitgescheden waardoor het Cu en Zn-gehalte in de mest wordt verdund. In de CVB Veevoedertabel wordt voor vleeskuikens geen verteerbaarheid van de drogestof van voedermiddelen vermeld. De verteerbaarheid van de organische stof (OS) kan echter wel berekend worden op basis van de vermelde verteerbaarheid van ruw eiwit (RE), ruw vet (RVETh) en overige koolhydraten (Okh), waarbij wordt verondersteld dat ruwe celstof (RC) voor vleeskuikens volledig onverteerbaar is. Deze werkwijze is gevolg voor een gemiddeld vleeskuikenvoer zoals geoptimaliseerd in 2017 voor de berekening van de TAN-excretie (totaal ammoniakaal stikstof) van de Nederlandse vleeskuikenhouderij (Bikker et al., 2011).

Om de DS-excretie te berekenen is naast de verteerbaarheid van de organische stof kennis nodig van de excretie van anorganische stof (AS). Hiervoor geeft de CVB-veevoedertabel geen informatie. De excretie van anorganische stof kan echter wel berekend worden als verschil tussen de opname van AS met het voer en de retentie van AS in het dier. Op deze wijze wordt geen onderscheid gemaakt tussen excretie in feces en urine, wat ook niet nodig is omdat beide in de excreta in de strooiselmest terechtkomen.

AS-retentie $(\%)=[$ Groei $(\mathrm{kg}) \times$ AS-gehalte in dier $(\mathrm{g} / \mathrm{kg})] /[($ Voeropname $(\mathrm{kg}) \times$ AS-gehalte in voer $(\mathrm{g} / \mathrm{kg})] \times 100 \%$.

Om de retentie te bepalen is van een aantal vleeskuikens uit eerder uitgevoerde experimenten het ASgehalte in het lichaam bepaald. Met behulp van dit gemiddeld AS-gehalte in het dier, de gemiddelde voederconversie (paragraaf 4.3) en het AS-gehalte in een gemiddeld vleeskuikenvoer is de relatieve AS-retentie berekend. Tenslotte is de DS-verteerbaarheid berekend als het gewogen gemiddelde van de OS-verteerbaarheid en de AS-retentie.

\subsubsection{Resultaten}

De gemiddelde voersamenstelling die is gebruikt voor het bepalen van de DS-verteerbaarheid is weergegeven in Bijlage 4. Op basis van de verteerbaarheid van ruw eiwit, ruw vet, ruwe celstof en overige koolhydraten bedroeg de verteerbaarheid van de OS 76\%. Op basis van een gemiddeld asgehalte van vleeskuikens bij slachten van $24 \%$ werd een gemiddelde as-retentie van $31 \%$ berekend Combinatie van deze twee resultaten en het OS- en AS-gehalte van het leverde een gemiddelde DSverteerbaarheid van $73 \%$. Deze waarde komt goed overeen met de bepaalde DS-verteerbaarheid in verteringsstudies met voeders die redelijk met praktijkvoeders overeenkwamen (Jansman en Van Diepen, 2010; Veldkamp e.a., 2014) en expert judgement (C. Kwakernaak, Schothorst Feed Research, persoonlijke mededeling).

\subsection{De vastlegging van koper en zink in vleeskuikens}

\subsubsection{Methode}

Om de retentie (vastlegging) van $\mathrm{Cu}$ en $\mathrm{Zn}$ in het vleeskuiken te kunnen berekenen dienen de gehalten aan $\mathrm{Cu}$ en $\mathrm{Zn}$ in het dier bekend te zijn. Bij varkens bedraagt de retentie voor Cu circa $2 \%$ (uitgaande van $20 \mathrm{mg} \mathrm{Cu} / \mathrm{kg}$ voer) en voor $\mathrm{Zn}$ circa 6\% (uitgaande van $120 \mathrm{mg} \mathrm{Zn} / \mathrm{kg}$ voer). Bij vleeskuikens zijn maar weinig proeven voorhanden waarbij de uitscheiding en vastlegging van $\mathrm{Cu}$ en $\mathrm{Zn}$ is bepaald. In eerste instantie is getracht op basis van literatuur het gemiddelde gehalte aan $\mathrm{Cu}$ en 
$\mathrm{Zn}$ in het dier vast te stellen (Bijlage 5). Het Cu gehalte van kuikens varieerde echter enorm tussen publicaties van circa $1-13 \mathrm{mg} / \mathrm{kg}$, waarbij de studie van Versteegh en Jongbloed (1998) zeer hoge kopergehalten vermeldde. Het zinkgehalte van kuikens varieerde van 14 tot $24 \mathrm{mg} / \mathrm{kg}$, en bedroeg gemiddeld $19 \mathrm{mg} / \mathrm{kg}$. De beschikbare data waren, op één studie na, afkomstig van studies van voor het jaar 2000. Vanwege de variatie in gevonden resultaten en mogelijke invloed van ontwikkelingen in de vleeskuikenhouderij sinds 2000 werd een actualisatie noodzakelijk geacht. Daarom is in een selectie van Ross 308 kuikens van verschillende leeftijd en sekse, afkomstig van eerder onderzoek van Wageningen Livestock Research het gehalte aan DS, AS, Cu en Zn bepaald door RIKILT Wageningen University \& Research.

\subsubsection{Resultaten}

In Tabel 7 staan de resultaten van de uitgevoerde Cu- en $\mathrm{Zn}$-analyses in vleeskuikens vermeld. De koper- en zinkgehalten van deze kuikens komt goed overeen met de gehalten uit de literatuur behalve waar het de kopergehalten in Versteegh en Jongbloed (1998) betreft. Deze resultaten lijken ons niet correct en hebben we verder buiten beschouwing gelaten. Op basis van de beschikbare resultaten bedraagt het gemiddeld gehalte aan Cu 1,2 mg/kg en Zn 18,2 mg/kg. Deze waarden zijn in het model gebruikt.

Tabel $7 \quad$ Koper- en zink gehalten van vleeskuikens op verschillende leeftijden (referentiejaar: 2015/2016).

\begin{tabular}{rrrr} 
Leeftijd & Vocht $(\mathrm{g} / \mathrm{kg})$ & Koper $(\mathrm{mg} / \mathrm{kg})$ & Zink (mg/kg) \\
0 & 828 & 0,7 & 13,2 \\
\hline 9 & 711 & 1,7 & 17,3 \\
\hline 18 & 677 & 1,0 & 16,0 \\
\hline 28 & 667 & 0,9 & 16,7 \\
\hline 35 & 654 & 0,9 & 19,7 \\
\hline 37 & 643 & 0,9 & 16,5 \\
\hline
\end{tabular}

Wanneer deze gehalten worden ingebracht in het excretiemodel (Bikker e.a. 2013) en er van uitgaande dat er in de het voer de maximaal toegelaten gehalten aan $\mathrm{Cu}$ en $\mathrm{Zn}$ zitten dan bedraagt $\mathrm{Cu}$ - en Zn-excretie per kuiken respectievelijk 90 en 515 mg. Van de aangevoerde Cu en Zn wordt respectievelijk 3,0\% en $7,5 \%$ vastgelegd in het dier (Tabel 8 ). 
Tabel 8 Berekende opname, vastlegging en excretie van koper en zink per kuiken bij voeders met maximaal toegestane hoeveelheden $\mathrm{Cu}$ en $\mathrm{Zn}$.

\begin{tabular}{|c|c|c|c|}
\hline & Eenheid & $\mathrm{Cu}$ & $\mathrm{Zn}$ \\
\hline Lengte productieperiode ${ }^{1}$ & d & 41 & 41 \\
\hline Begingewicht kuiken & $\mathrm{g}$ & 42 & 42 \\
\hline Gemiddeld eindgewicht ${ }^{1}$ & $\mathrm{~g}$ & 2250 & 2280 \\
\hline Voerconversie $^{1}$ & & 1,64 & 1,63 \\
\hline Uitval & $\%$ & 3,5 & 3,5 \\
\hline Gewicht uitval & $\mathrm{g}$ & 740,0 & 740,0 \\
\hline Gehalte in uitval & $\mathrm{mg} / \mathrm{kg}$ & 1,2 & 18,2 \\
\hline Groei & $g / d$ & 54,6 & 54,6 \\
\hline Gehalte dier (dag 0) & $\mathrm{mg} / \mathrm{kg}$ & 1,2 & 18,2 \\
\hline Gehalte dier (eind) & $\mathrm{mg} / \mathrm{kg}$ & 1,2 & 18,2 \\
\hline Totale voeropname & $\mathrm{g}$ & 3716 & 3716 \\
\hline$\%$ startvoer & $\%$ & 8,2 & 8,2 \\
\hline$\%$ groeivoer I & $\%$ & 13,7 & 13,7 \\
\hline$\%$ groeivoer II & $\%$ & 37,0 & 37,0 \\
\hline$\%$ eindvoer & $\%$ & 41,1 & 41,1 \\
\hline Aandeel startvoer & $\mathrm{g}$ & 305 & 305 \\
\hline Gehalte aan mineraal startvoer & $\mathrm{mg} / \mathrm{kg}$ & 25 & 150 \\
\hline Aandeel groeivoer I & $\mathrm{g}$ & 509 & 509 \\
\hline Gehalte aan mineraal groeivoer I & $\mathrm{mg} / \mathrm{kg}$ & 25 & 150 \\
\hline Aandeel groeivoer II & $\mathrm{g}$ & 1375 & 1375 \\
\hline Gehalte aan mineraal groeivoer II & $\mathrm{mg} / \mathrm{kg}$ & 25 & 150 \\
\hline Aandeel eindvoer & $\mathrm{g}$ & 1527 & 1527 \\
\hline Gehalte aan mineraal eindvoer & $\mathrm{mg} / \mathrm{kg}$ & 25 & 150 \\
\hline \multicolumn{4}{|l|}{ Mineralen opname per kuiken } \\
\hline Startvoer & $\mathrm{mg}$ & 7,6 & 45,7 \\
\hline Groeivoer I & $\mathrm{mg}$ & 12,7 & 76,4 \\
\hline Groeivoer II & $\mathrm{mg}$ & 34,4 & 206,3 \\
\hline Eindvoer & $\mathrm{mg}$ & 38,2 & 229,1 \\
\hline Totale mineraal opname $(A)$ & mg & 92,9 & 557,5 \\
\hline \multicolumn{4}{|l|}{ Mineraal vastlegging per kuiken } \\
\hline Vlees & $\mathrm{mg}$ & 2,74 & 41,5 \\
\hline Uitval & $\mathrm{mg}$ & 0,03 & 0,5 \\
\hline Totale mineraal vastlegging $(B)$ & mg & 2,8 & 42,0 \\
\hline Mineraal excretie (A-B) & mg & 90,1 & 515,5 \\
\hline Vastlegging \% & $\%$ & 3,0 & 7,5 \\
\hline
\end{tabular}




\subsection{Groeiprestaties van de dieren en bezettingsdichtheid}

\subsubsection{Methode}

Om de totale drogestofexcretie te kunnen berekenen is naast de samenstelling en verteerbaarheid van het voer (paragraaf 4.2) informatie nodig over de voeropname en groei van de vleeskuikens, de bezetting per eenheid staloppervlakte en de uitval gedurende het groeitraject. Voor de voeropname en groei is gebruik gemaakt van de groeicurve van Ross 308, aangezien dit het meest gebruikte vleeskuiken is in Nederland. De gebruiker kan in het model de groei en/of het voerverbruik zodanig aanpassen dat deze overeenkomt met de specifieke bedrijfssituatie. Voor de uitval is uitgegaan van de berekening van de maximale uitval in het kader van het vleeskuikenbesluit, waarbij de uitval in de eerste 7 dagen $1,5 \%$ bedraagt (dit is $0,2 \%$ per dag) en daarna $0,06 \%$ per dag. De rekenregel is als volgt: $1,5 \%+0,06 \% \times$ leeftijd dieren in dagen. Voor de bezetting bij opzet is een waarde van 21,5 kuikens per $\mathrm{m}^{2}$ aangenomen (KWIN-V 2017/2018).

\subsubsection{Resultaten}

De gebruikte standaardgroeicurve is weergegeven in Bijlage 6. Voor de bezetting is uitgegaan van 21,5 kuikens/ $\mathrm{m}^{2}$ bij opzet. Deze bezetting kan handmatig worden aangepast aan de bedrijfsspecifieke situatie. Voor de uitval wordt standaard gerekend met de hierboven genoemde rekenregel, maar ook deze is aan te passen aan de bedrijfsspecifieke situatie. In het model kunnen de standaardwaarden door de gebruiker worden aangepast om de resultaten beter te laten aansluiten bij de situatie op een individueel vleeskuikenbedrijf. Voor voeropname en groei kan gebruik gemaakt worden van een schaalfactor om de gehele curve met een bepaald percentage te laten stijgen of dalen.

\subsubsection{Praktische uitvoering}

Op basis van de leeftijd van de kuikens kan de cumulatieve voeropname tot aan het moment van monstername worden bepaald. Vleeskuikenbedrijven registreren meestal zelf de (dagelijkse) voeropname. Indien dit niet wordt of kan worden gedaan, dan is het mogelijk aan de hand van de leeftijd van de kuikens en normlijsten (bijv. hokkaarten van de voerleverancier of dierenarts) het cumulatieve voerverbruik te berekenen.

De bezettingsdichtheid heeft invloed op de hoeveelheid mest die wordt geproduceerd per oppervlakteeenheid. De bezettingsdichtheid is te berekenen door het aantal opgezette / geplaatste kuikens te delen door het aantal vierkante meter staloppervlak. De oppervlakte kan worden afgeleid uit de plattegrond van de stal (deze is meestal wel beschikbaar) of ter plekke worden opgemeten. Bovenstaande gegevens moeten in het kader van de Welzijnswetgeving voor bedrijven die een hogere bezettingsdichtheid willen hanteren dan $33 \mathrm{~kg} / \mathrm{m}^{2}$ (de zgn. categorie 2 en 3 vleeskuikenbedrijven) worden vastgelegd. Welke bezetting een vleeskuikenhouder in een bepaalde stal mag hanteren is afhankelijk van de uitval en de voetzoollaesiescore in het voorliggende jaar (zie hoofdstuk 2 en Bijlage 1 en 2), maar deze mag niet boven de 39 of $42 \mathrm{~kg} / \mathrm{m}^{2}$ uitkomen.

De leeftijd van de kuikens op het moment van monstername en de gehanteerde bezetting is te achterhalen uit de administratie. Vaak vermeldt de hoklijst het aantal opgezette kuikens en de datum van opzet, anderzijds is het aantal kuikens en de opzetdatum (= datum van levering kuikens) terug te vinden op de afleverbon van de broederij. Tevens dient een bedrijf per stal/koppel dagelijks de uitval te registreren. Verder zijn er bedrijven die tijdens de productieperiode één of meerdere keren uitladen (= het tussentijds afleveren van een deel van de dieren aan de slachterij). Het moment van uitladen en aantal dieren dat wordt uitgeladen wordt normaliter ook vastgelegd in de hok-/staladministratie. Daarnaast is het aantal dieren dat wordt uitgeladen ook te achterhalen aan de hand van de slachterijafrekeningen. 


\subsection{Samenstelling en gebruik van strooiselmateriaal}

\subsubsection{Methode}

Vleeskuikens lopen op een (betonnen) vloer bedekt met strooisel, zoals houtkrullen, gehakseld tarwestro of turf. Het strooisel wordt voor de opzet (plaatsing) van de eendagskuikens ingebracht in de stal. De hoeveelheid strooisel per oppervlakte eenheid varieert en is afhankelijk van de stal (o.a. de mate van isolatie van de vloer en de aanwezigheid van vloerverwarming), het soort strooiselmateriaal, het seizoen, de kosten van het strooiselmateriaal en voorkeur van de vleeskuikenhouder voor een dunne laag of een dikke(re) laag strooisel. Gemiddeld bedraagt de hoeveelheid strooisel die wordt ingebracht $1 \mathrm{~kg} / \mathrm{m}^{2}$ (KWIN-V 2017-2018). Dit wordt in het model gebruikt als default waarde en kan door de gebruiker worden aangepast. Het strooisel blijft gedurende de gehele productieperiode liggen en wordt pas verwijderd na het afleveren van de kuikens naar de slachterij. Het aflevermoment varieert veelal tussen 36 en 48 dagen leeftijd (KWIN-V 2017-2018; gemiddeld afleverleeftijd 41 dagen). Dit betekent dat het aandeel mest toeneemt en het aandeel strooisel afneemt met het ouder worden van de kuikens.

Inzicht in het gebruik en het $\mathrm{Cu}$ - en Zn-gehalte in het strooiselmateriaal is noodzakelijk om in te kunnen schatten hoeveel $\mathrm{Cu}$ en $\mathrm{Zn}$ in strooiselmest van schoon strooiselmateriaal afkomstig kan zijn. Om dit in beeld te krijgen zijn een aantal leveranciers van strooiselmateriaal benaderd met de vraag om schoon strooiselmateriaal in te zenden voor analyse van het gehalte aan drogestof, anorganische stof, Cu en Zn. Daarnaast zijn bij bedrijfsbezoeken in het kader van een studie naar ammoniakemissie uit vleeskuikenstallen (Aarnink et al., 2016), indien beschikbaar, monsters van strooiselmateriaal genomen. Ook in deze monsters werden de eerder genoemde gehalten bepaald. In totaal zijn er op deze wijze 22 monsters verzameld en geanalyseerd. De analyses in het strooiselmateriaal werden uitgevoerd door RIKILT Wageningen University \& Research.

\subsubsection{Resultaten}

\subsubsection{Verhouding strooisel en mest}

Bij opzet van de kuikens is het aandeel strooisel $100 \%$ en het aandeel mest $0 \%$. Hoe deze verhouding ligt in de loop van de productieperiode is o.a. afhankelijk van het drogestofgehalte van de verse mest, de drogestofverteerbaarheid van het voer, de hoeveelheid en droogcapaciteit van de ventilatielucht en de verliezen door broei. Het model werkt op drogestofbasis waardoor drogestofgehalte van de mest en droogcapaciteit geen invloed hebben. De hoeveelheid ingebracht strooisel bij opzet, de drogestofverteerbaarheid van het voer en de voeropname spelen zijn de belangrijkste invloedsfactoren. In Figuur 4 wordt het verloop van het aandeel drogestof uit strooisel in strooiselmest tijdens de productieperiode weergegeven. Het aandeel drogestof uit strooisel in de strooiselmest is iets hoger bij een hogere verteerbaarheid van het voer en neemt af gedurende het groeitraject.

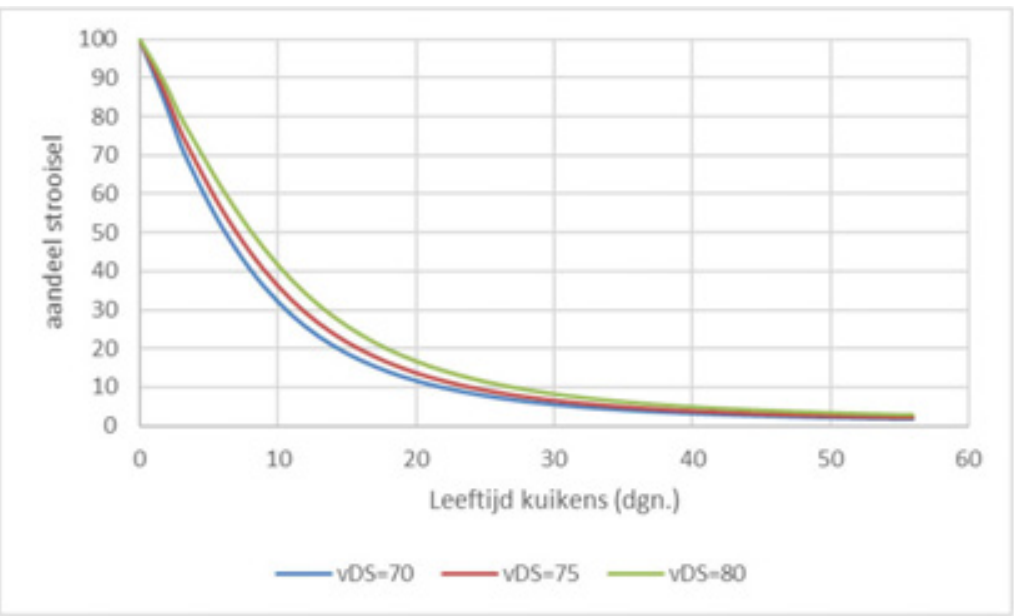

Figuur 4 Verloop van het aandeel drogestof uit strooiselmateriaal in strooiselmest gedurende de productieperiode van vleeskuikens in afhankelijkheid van de drogestofverteerbaarheid van het voer. 


\subsubsection{Samenstelling van strooisel}

In Tabel 9 worden de gemiddelde drogestof, koper en zinkgehalten van een tiental strooiselmaterialen vermeld. Met uitzondering van turfstrooisel zijn de gehalten aan koper en zink in strooiselmaterialen gering. Het $\mathrm{Cu}$ en $\mathrm{Zn}$ gehalte van een eerste analyse van turfstrooisel bedroeg gemiddeld respectievelijk 29 en 234 mg/kg, met een zeer groot verschil tussen de twee betreffende monsters. Bij de analyse van een tweede set monsters werd een veel lager $\mathrm{Cu}$ - en $\mathrm{Zn}$-gehalte gevonden met veel minder spreiding tussen de monsters.

Tabel 9 Drogestof-, koper- en zinkgehalten strooiselmaterialen.

\begin{tabular}{|c|c|c|c|c|}
\hline Type strooiselmateriaal & n monsters & Droge stof $(\%)$ & Koper (mg/kg) & Zink (mg/kg) \\
\hline CocoDry droog & 1 & 79,4 & 3,8 & 9,5 \\
\hline CocoDry licht vochtig & 1 & 30,1 & $<2,0$ & 4,8 \\
\hline Gehakseld hennep & 1 & 91,7 & 2,6 & 10,1 \\
\hline Houtkrullen & 8 & 90,4 & $4,1 \pm 1,7$ & $10,6 \pm 1,0$ \\
\hline Strokorrels & 1 & 94,8 & $<2,0$ & 19,9 \\
\hline Tarwestro & 3 & 91,4 & $2,0 \pm 0,5$ & $5,5 \pm 1,3$ \\
\hline Turf, $1^{\mathrm{e}}$ set monsters & 2 & 85,7 & $29 \pm 27$ & $234 \pm 241$ \\
\hline Turf, $2^{\mathrm{e}}$ set monsters & 4 & 51,6 & $1,1 \pm 0,2$ & $10,2 \pm 2,4$ \\
\hline
\end{tabular}

CoCo Dry ${ }^{\circledR}$ is samengesteld uit plantenresten, waaronder kokos, die een behandeling hebben ondergaan onder hoge druk en hoge temperaturen voor de productie van oliën voor de farmaceutische en cosmetische industrie.

Ecosoft ${ }^{\circledR}$ bestaat uit plantenresten, die onder hoge druk en hoge temperatuur zijn uitgeperst voor de winning van oliën voor de cosmetische en farmaceutische industrie.

In de 1 e set van twee turfmonsters was het Cu-gehalte 47,5 en 9,5 g/kg en het zinkgehalte 404 en $64 \mathrm{mg} / \mathrm{kg}$. In de $2 \mathrm{e}$ set monsters was de spreiding beduidend kleiner.

De invloed van het gebruikte strooiselmateriaal op het Cu en Zn-gehalte in strooiselmest daalt met het toenemen van de leeftijd van de kuikens. Het aandeel uit strooisel neemt af van 100 (bij opzet) naar minder dan $1 \%$ procent aan het eind van de productieperiode (Figuur 5 ). Dus ook bij turf, een strooiselmateriaal met relatief hoge $\mathrm{Cu}$ en $\mathrm{Zn}$ gehalten, is de invloed op het $\mathrm{Cu}$ en $\mathrm{Zn}$ gehalte van de strooiselmest beperkt. In Figuur 6 is het verloop van het $\mathrm{Cu}$ en $\mathrm{Zn}$ gehalte in de strooiselmest weergegeven. Het gehalte neemt curvilineair toe door een afnemend (verdunnend) effect van het strooiselmateriaal.

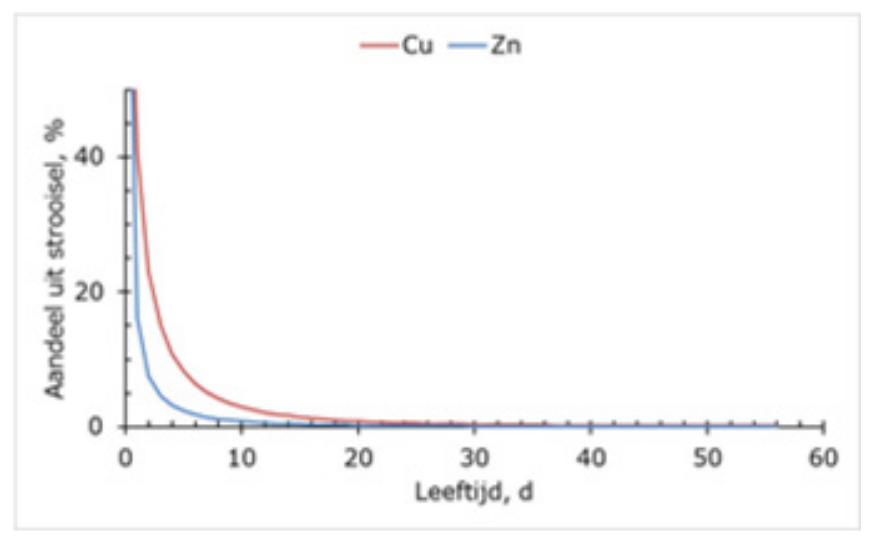

Figur $5 \quad$ Verloop van het aandeel koper en zink uit houtkrullen in strooiselmest gedurende de productieperiode van vleeskuikens. 

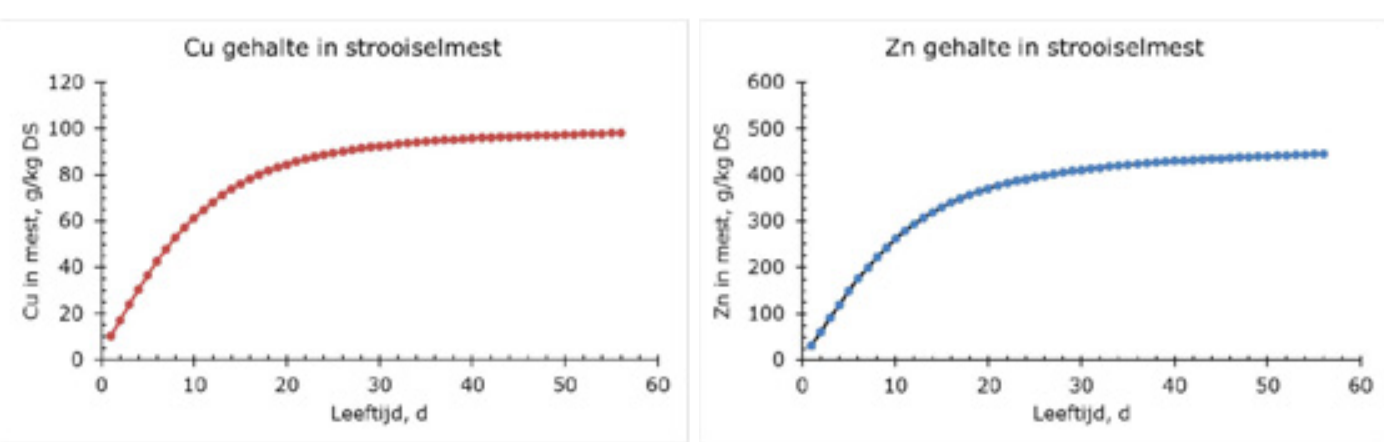

Figuur 6 Verloop van het koper en zinkgehalte in drogestof van strooiselmest gedurende de productieperiode van vleeskuikens.

\subsubsection{Praktische uitvoering}

De hoeveelheid en het soort strooiselmateriaal zijn te achterhalen via aankoopbonnen. Lastiger wordt het als een vleeskuikenhouder strooiselmateriaal van eigen bedrijf gebruikt waarbij de hoeveelheid materiaal vaak niet exact bekend en vastgelegd is. De meeste vleeskuikenbedrijven in Nederland hanteren een bezetting van meer dan 33 kilogram per vierkante meter. Om deze bezetting (bezettingscategorie 2 of 3) te mogen hanteren dienen vleeskuikenhouders in het kader van het Vleeskuikenbesluit een aantal zaken te documenteren, waaronder een plattegrond van de stal met de afmetingen van de bruto staloppervlakte ${ }^{3}$ en het gebruikte strooisel. Bij de meeste bedrijven is dus het staloppervlakte bekend. Hierdoor is het mogelijk de hoeveelheid strooisel per oppervlakte-eenheid in te schatten. Bij stallen met een bezettingsdichtheid van minder of gelijk aan $33 \mathrm{~kg} / \mathrm{m}^{2}$

(bezettingscategorie 1) kan ter plaatse het bruto staloppervlak worden opgemeten. Eventueel kan dit ook worden geverifieerd met de bouwtekening van de desbetreffende stal. Indien er onduidelijkheid bestaat over het gebruikte strooiselmateriaal dan is het mogelijk via macro- of microscopie te achterhalen welk strooiselmateriaal is gebruikt. De noodzaak hiervan is echter beperkt aangezien de bijdrage van het gebruikte strooiselmateriaal aan het totaal koper en zink gehalte in de strooiselmest gering is.

Wanneer de strooiselkwaliteit slecht is kan worden bijgestrooid. Dit betekent dat er nieuw strooiselmateriaal wordt aangebracht (gestrooid) over het 'oude' mengsel van strooisel en mest. Dit wordt gedaan ter voorkoming van afkeuringen op de slachterij vanwege huidirritaties. In dat geval is de vraag of een vleeskuikenhouder de hoeveelheid bijgestrooid strooisel exact weet en registreert. Wellicht zal deze alleen een schatting kunnen geven van het aantal balen dat hij heeft bijgestrooid, waarbij ook het gewicht van deze balen niet (exact) bekend is. Het model biedt de mogelijkheid de invloed van extra strooisel te verwerken.

\subsection{Gevoeligheidsanalyse}

Op basis van de verzamelde informatie is een model gemaakt waarmee de Cu en Zn gehalten van de strooiselmest kunnen worden berekend op basis van de hiervoor besproken invoergegevens. Voor de meeste invoergegevens zijn standaardwaarden opgenomen die door de gebruiker kunnen worden aangepast op basis van de actuele situatie. Een aantal gegevens zullen echter niet exact bekend zijn. Daarom is van belang welke invloed onzekerheid of variatie in deze kenmerken heeft op de $\mathrm{Cu}$ en $\mathrm{Zn}$ gehalten in strooiselmest. Van de belangrijkste factoren is nagegaan welke invloed de verwachte of gevonden spreiding heeft op het berekende $\mathrm{Cu}$ en Zn-gehalte van de strooiselmest op dag 35 van de groeiperiode weergegeven. Uit de resultaten in Tabel 10 en 11 blijkt met name dat de drogestofverteerbaarheid van het voer een grote invloed heeft op het $\mathrm{Cu}$ en $\mathrm{Zn}$ gehalte in de

\footnotetext{
3 Bruto bruikbare oppervlakte. Dit is de binnenmaatse oppervlakte van de stal die bedekt is met strooisel en toegankelijk is voor vleeskuikens. Is de voervoorziening niet oplierbaar? Dan telt de netto bruikbare oppervlakte. Dit is de bruto bruikbare oppervlakte $\min 1,7 \%$.
} 
strooiselmest. Ook de ingebrachte hoeveelheid strooisel en de mate van broei (warmteontwikkeling in de strooiselmest door microbiële activiteit in het strooisel waardoor organisch materiaal wordt afgebroken) hebben een aanzienlijk effect omdat hierdoor de hoeveelheid drogestof en daarmee de verdunning van $\mathrm{Cu}$ en $\mathrm{Zn}$-gehalte wordt bepaald. Hoe nauwkeuriger deze variabelen bekend zijn, hoe betrouwbaarder de gehalten in de strooiselmest kunnen worden bepaald. De overige factoren, waaronder het $\mathrm{Cu}$ en $\mathrm{Zn}$ gehalte in het dier en in strooisel en de groeiprestaties en uitval van de dieren hebben een beperkte invloed.

Tabel 10 Effect van variatie in verschillende factoren op het berekend Cu gehalte van de strooiselmest op 35 dagen leeftijd.

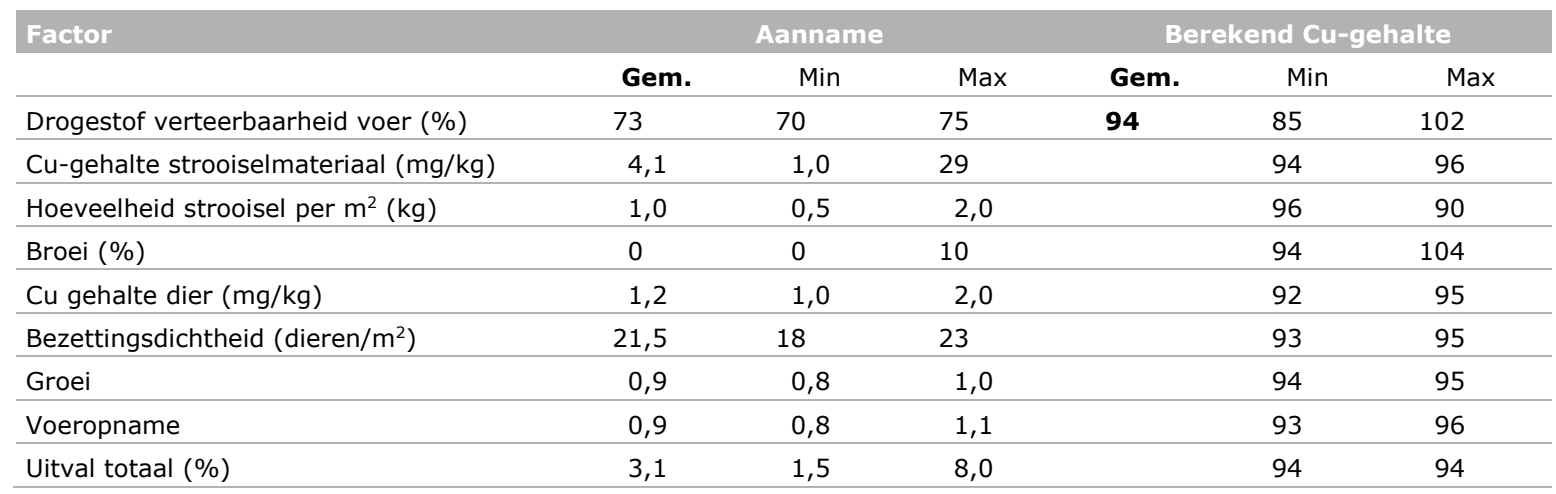

Tabel 11 Effecten van variatie in verschillende factoren op het berekend Zn gehalte van de strooiselmest op 35 dagen leeftijd.

\begin{tabular}{|c|c|c|c|c|c|c|}
\hline \multirow[t]{2}{*}{ Factor } & \multicolumn{3}{|c|}{ Aanname } & \multicolumn{3}{|c|}{ Berekend Zn-gehalte } \\
\hline & Gem. & Min & Max & Gem. & Min & Max \\
\hline Drogestof verteerbaarheid voer (\%) & 73 & 70 & 80 & 422 & 382 & 454 \\
\hline Hoeveelheid strooisel per $\mathrm{m}^{2}(\mathrm{~kg})$ & 1,0 & 0,5 & 2,0 & & 434 & 400 \\
\hline Broei (\%) & 0 & 0 & 10 & & 422 & 466 \\
\hline Bezettingsdichtheid (dieren/m²) & 21,5 & 18,0 & 23,0 & & 417 & 423 \\
\hline Groei & 0,9 & 0,8 & 1,0 & & 417 & 427 \\
\hline Voeropname & 0,9 & 0,8 & 1,1 & & 413 & 434 \\
\hline Uitval totaal (\%) & 3,1 & 1,5 & 8,0 & & 421 & 422 \\
\hline
\end{tabular}




\section{$5 \quad$ Monstername en modelvalidatie}

\subsection{Methode}

Om het hiervoor beschreven model in de praktijk te kunnen gebruiken en valideren was het noodzakelijk strooiselmestmonsters te verzamelen op een aantal vleeskuikenbedrijven en de berekende $\mathrm{Zn}$ - en $\mathrm{Cu}$-gehalten in de mest te vergelijken met de geanalyseerde gehalten. De benodigde monstername werd gecombineerd met een ander onderzoekproject ten behoeve van de ontwikkeling van een model waarmee de ammoniakemissie uit vleeskuikenstallen kan worden berekend (Aarnink et al., 2016). Voor een verdere verfijning van dit model zijn er in 33 stallen van 14 bedrijven strooiselmestmonsters genomen voor nadere analyse. De (per stal gepoolde) monsters zijn tevens gebruikt voor het bepalen van het $\mathrm{Cu}$ - en $\mathrm{Zn}$-gehalte in strooiselmest. Hierbij is gebruik gemaakt van het bemonsteringsprotocol zoals beschreven in Bijlage 7. In dit protocol wordt uit een aantal deelmonsters van verschillende plaatsen in de stal één gepoold monster per stal samengesteld. Het ontbrak echter aan inzicht in de variatie in $\mathrm{Cu}$ - en $\mathrm{Zn}$-gehalte in strooiselmest van verschillende plaatsen in de stal. Daarom zijn op één bedrijf monsters genomen van een aantal vooraf gedefinieerde plaatsten in de stal en individueel geanalyseerd. Dit wordt in onderstaande paragraaf nader toegelicht.

\subsubsection{Variatie in strooiselmest binnen een stal}

In een vleeskuikenstal bevinden zich in de lengterichting voer- en of drinklijnen. Hierdoor kunnen er verschillen ontstaan in kwaliteit en samenstelling van het strooisel. Zo is de strooiselmest in de nabijheid van de drinklijnen vaak vochtiger dan de strooiselmest in de nabijheid van de voerlijnen. Daarnaast speelt ook het mestgedrag van de kuikens en rol. De vraag hierbij is of de mestproductie egaal over het staloppervlak plaatsvindt of dat er plaatsen zijn waar meer of vaker mest wordt gedeponeerd. Dit laatste zou kunnen leiden tot variatie in $\mathrm{Cu}$ en $\mathrm{Zn}$ gehalten binnen een stal. Over variatie in $\mathrm{Cu}$ en $\mathrm{Zn}$ gehalten op verschillende plekken in een stal waren ons geen gegevens bekend. In de eerder genoemde studie bij varkens kon op basis van uitgevoerde verteringsproeven een goede inschatting worden gemaakt van de variatie van het $\mathrm{Cu}$ - en $\mathrm{Zn}$-gehalte in de drogestof van de mest tussen hokken, zodat een uitspraak gedaan kon worden over het aantal te bemonsteren hokken. Het bleek dat bij varkens de variatie in $\mathrm{Cu}$ en $\mathrm{Zn}$ gehalten tussen hokken zeer gering was en dat volstaan kon worden met één gepoold monster van één hok of eventueel meerdere hokken. Vanwege het ontbreken van informatie over $\mathrm{Cu}$ en $\mathrm{Zn}$ gehalten in strooiselmest op verschillende locaties in de stal enerzijds en het ontbreken van $\mathrm{Cu}$ en $\mathrm{Zn}$ verteringstudies anderzijds is het bij vleeskuikens lastig een inschatting te maken van de variatie in $\mathrm{Cu}$ - en $\mathrm{Zn}$-gehalten op diverse plaatsen in een stal en dus ook van het benodigd aantal te bemonsteren plaatsen in een stal. Daarom was het gewenst de variatie in kaart te brengen. Hiertoe werd in één stal op 10 verschillende plekken strooiselmestmonsters genomen. De monsternamelocaties kwamen overeen met de bemonsteringsplekken van het protocol (zie Bijlage 7). De monsters werden door het RIKILT Wageningen University \& Research geanalyseerd op droge stof, Cu en Zn. Daarnaast werd het gepoolde monster (conform protocol) op deze parameters geanalyseerd.

\subsubsection{Cu en Zn gehalten in strooiselmest}

Vleeskuikens scheiden mest en urine gelijktijdig in (min of meer) vaste vorm uit en dit 'mengsel' wordt uitgescheiden op het strooiselmateriaal. Er dus bij vleeskuikens geen sprake van aparte uitscheiding van mest en urine, zoals dat bij varkens wel het geval is. Voor vleeskuikens behoeft er dus niet gecorrigeerd te worden voor urine aangezien deze wordt meegenomen bij bemonstering van de strooiselmest.

$\mathrm{Er}$ is zeer weinig bekend over de $\mathrm{Cu}$ en Zn gehalten van Nederlandse vleeskuikenmest. Een van de weinige studies na 2003 waarbij gekeken is naar de Cu en Zn gehalten in vleeskuikenmest is de studie van Römkens en Rietra (2008). Zij hebben in 2007 onderzoek gedaan naar de koper en zinkgehalten in runder-, varkens- en kippenmest om kennis van de gehalten aan zware metalen in mest te 
actualiseren en na te gaan of de verlaging van maximale gehalten aan $\mathrm{Cu}$ en $\mathrm{Zn}$ in veevoer (EU, 2003) hadden geleid tot lagere $\mathrm{Cu}$ en $\mathrm{Zn}$ gehalten in de mest. In totaal werden 40 mestmonsters (representatief voor de geografische verdeling van bedrijven in Nederland) geanalyseerd. In Tabel 12 worden de minimum, mediaan, gemiddelde en maximum drogestof-, koper- en zinkgehalten weergegeven. De gehalten aan $\mathrm{Cu}$ en $\mathrm{Zn}$ in vleeskuikenmest waren ten opzichte van eerdere analyses in 1996 gedaald met respectievelijk 43 en 15 procent.

Tabel 12 Koper- en zinkgehalten in vleeskuikenmest $(n=40)$ in 2007 (Bron: Römkens en Rietra, 2008)

\begin{tabular}{lccc}
$\mathrm{n}=40$ & Droge stof $(\mathrm{g} / \mathrm{kg})$ & Koper $(\mathrm{mg} / \mathrm{kg}$ DS $)$ & Zink $(\mathrm{mg} / \mathrm{kg}$ DS $)$ \\
Minimum & 538 & 44 & 205 \\
\hline Mediaan & 683 & 78 & 266 \\
\hline Gemiddeld & 696 & 86 & 297 \\
\hline Maximum & 912 & 171 & 607 \\
\hline
\end{tabular}

In hoeverre de gevonden $\mathrm{Cu}$ en Zn gehalten van Römkens en Rietra (2008) nog actueel zijn is niet bekend, deze resultaten worden vergeleken met de analyse van de mestmonsters in de huidige studie.

\subsubsection{Validatie}

Om het ontwikkelde model te valideren is bij de betrokken bedrijven tevens zoveel mogelijk informatie verzameld over de Cu- en Zn-gehalten in voer, gebruik van drinkwatersupplementen, groeiprestatie, en gebruik van strooisel om deze als inputfactoren in het model te gebruiken. Vervolgens zijn de berekende en geanalyseerde gehalten aan $\mathrm{Cu}$ en $\mathrm{Zn}$ in strooiselmest met elkaar vergeleken.

\subsection{Resultaten}

\subsubsection{Variatie in strooiselmest binnen een stal}

Het bleek dat het gemiddelde droge stof-, koper- en zinkgehalte van de tien monsters genomen van verschillende plaatsen binnen een stal redelijk overeenkwam met de gehalten van het gepoolde monster van deze stal. Er was wel een redelijk grote variatie in de drogestof-, koper en zinkgehalten tussen de verschillende monstername plekken (Tabel 13).

Tabel 13 Gemiddeld, minimum, maximum en standaard deviatie van drogestof-, koper- en zinkgehalten in vleeskuikenmest op tien verschillende locaties in de stal en in het volgens protocol gepoolde monster.

\begin{tabular}{|c|c|c|c|c|c|c|}
\hline & Eenheid & Gemiddeld & Minimum & Maximum & Std.dev & Protocol \\
\hline Droge stof & $\mathrm{g} / \mathrm{kg}$ & 530 & 447 & 649 & 72 & 545 \\
\hline Koper & $\mathrm{mg} / \mathrm{kg}$ & 60 & 46 & 77 & 10 & 67 \\
\hline Zink & $\mathrm{mg} / \mathrm{kg}$ & 266 & 197 & 326 & 42 & 275 \\
\hline Zink & $\mathrm{mg} / \mathrm{kg} \mathrm{DS}$ & 500 & 432 & 542 & 41 & 506 \\
\hline
\end{tabular}

\subsubsection{Cu en Zn gehalten in strooiselmest}

In Tabel 14 worden de gemiddelde drogestof-, koper en zinkgehalten van de strooiselmest in deze stallen weergegeven. Het gemiddelde drogestofgehalte van de strooiselmest lag in vergelijking met de resultaten van Römkens en Rietra (2008) lager (560 vs. 696 g/kg), terwijl het gemiddelde koper- en zinkgehalte respectievelijk 22 en 63 procent hoger was in de huidige studie. Waardoor deze 
verschillen worden veroorzaakt is niet duidelijk en geen onderwerp van deze studie. Voor zover bekend werden er in geen van de bemonsterde stallen $\mathrm{Cu}$ en/of Zn-houdende (water)additieven gebruikt. Op basis van de hoeveelheid toegevoegd koper en zink zoals vermeld op de voerbonnen, kon ook niet geconcludeerd worden dat via het voer de wettelijke norm aan Cu en Zn werd overschreden. Opgemerkt wordt dat tussen 2000 en 2004 de Nederlandse diervoederindustrie op basis van een convenant zich vrijwillig had gecommitteerd aan een maximaal toevoeging van $15 \mathrm{mg} \mathrm{Cu}$ en $55 \mathrm{mg} \mathrm{Zn}$ per kg pluimveevoer. Dit kan hebben bijgedragen aan de lagere gehalten gerapporteerd door Römkens en Rietra (2008).

Aangezien er in Nederland vanaf 2013 bij vleeskuikens monitoring plaatsvindt op het voorkomen en ernst van voetzoollaesies, zou eerder een hoger dan een lager drogestofgehalte in mest worden verwacht dan in de eerdere studie. Het is bekend dat droger strooisel de kans op voetzoollaesies vermindert en vleeskuikenhouders willen voetzoollaesies voorkomen omdat dit direct consequenties heeft op de te hanteren bezetting in de stal en dus direct invloed heeft op het bedrijfsrendement. Het dient opgemerkt te worden dat het door Römkens en Rietra (2008) genoemde drogestofgehalte als vrij hoog wordt beschouwd. Zoons (2009) vond in een meerjarenonderzoek in België een gemiddeld drogestofgehalte van vleeskuikenstrooiselmest van $55 \%$.

Tabel 14 Gemiddeld, mediaan, minimum, maximum en standaard deviatie van drogestof-, koperen zinkgehalten in vleeskuikenmest gebaseerd op gepoolde monsters uit 33 vleeskuikenstallen in 2016.

\begin{tabular}{|c|c|c|c|c|c|c|}
\hline & Eenheid & Gemiddeld & Mediaan & Minimum & Maximum & Std.dev \\
\hline Droge stof & $\mathrm{g} / \mathrm{kg}$ & 560 & 557 & 455 & 679 & 61 \\
\hline Koper & $\mathrm{mg} / \mathrm{kg}$ & 58 & 54 & 40 & 102 & 15 \\
\hline Zink & $\mathrm{mg} / \mathrm{kg}$ & 272 & 280 & 175 & 360 & 43 \\
\hline Zink & $\mathrm{mg} / \mathrm{kg} \mathrm{DS}$ & 485 & 481 & 327 & 604 & 52 \\
\hline
\end{tabular}

\subsubsection{Berekende en geanalyseerde gehalten}

In Tabel 15 zijn de resultaten weergegeven van 8 rondes waarin het $\mathrm{Cu}$ en $\mathrm{Zn}$-gehalte in de mest is berekend met het model en vergeleken met geanalyseerde gehalten volgens het besproken monsterprotocol. De berekende en geanalyseerde gehalten kwamen over het algemeen goed met elkaar overeen. Het hogere Zn-gehalte op bedrijf 1 ten opzicht van bedrijf 2 werd veroorzaakt door een hoger $\mathrm{Zn}$-gehalte in het voer. Dit Zn-gehalte $(138 \mathrm{mg} / \mathrm{kg})$ ligt boven het huidige maximum toegestane gehalte maar was nog toegelaten ten tijde van de monstername. Het hogere Cu-gehalte op bedrijf 1 werd veroorzaakt door gebruik van een drinkwatersupplement met $\mathrm{Cu}$. Bij monstername was dit niet vermeld, maar dit werd door de pluimveehouder bevestigd nadat het modelresultaat er op duidde dat het Cu-gebruik hoger was dan door het voer kon worden verklaard.

Tabel 15 Berekende en geanalyseerde koper- en zinkgehalten in strooiselmest afkomstig uit verschillende stallen op tweetal verschillende bedrijven.

\begin{tabular}{|c|c|c|c|c|c|c|}
\hline \multirow[t]{2}{*}{ Datum bemonstering } & \multirow[t]{2}{*}{ Bedrijf + stal } & \multirow[t]{2}{*}{ Voerleverancier } & \multicolumn{2}{|c|}{ Berekend } & \multicolumn{2}{|c|}{ Geanalyseerd } \\
\hline & & & $\mathrm{Cu}$ & $\mathrm{Zn}$ & $\mathrm{Cu}$ & $\mathrm{Zn}$ \\
\hline $26-09-2016$ & Bedrijf 1 - Stal 1 & A & 105 & 504 & 116 & 515 \\
\hline $10-11-2016$ & Bedrijf 1 - Stal 1 & A & 123 & 510 & 123 & 506 \\
\hline $10-11-2016$ & Bedrijf 1 - Stal 3 & $A$ & 116 & 502 & 116 & 491 \\
\hline $20-09-2016$ & Bedrijf 2 - Stal 3 & $\mathrm{~B}$ & 84 & 446 & 94 & 496 \\
\hline $03-11-2016$ & Bedrijf 2 - Stal 1 & $\mathrm{C}$ & 83 & 429 & 79 & 434 \\
\hline 03-11-2016 & Bedrijf 2 - Stal 3 & $\mathrm{C}$ & 83 & 431 & 96 & 452 \\
\hline
\end{tabular}




\section{Conclusies en aanbevelingen}

Binnen dit project is een model ontwikkeld waarmee op basis van een aantal inputfactoren het $\mathrm{Cu}$ - en Zn-gehalte in strooiselmest van vleeskuikens kan worden berekend. Het model biedt daarmee de mogelijkheid de invloed van $\mathrm{Cu}$ en $\mathrm{Zn}$-gehalte in het voer en gebruik van drinkwatersupplementen met $\mathrm{Cu}$ en/of $\mathrm{Zn}$ op de excretie in de mest te bepalen. Door analyse van het $\mathrm{Cu}$ en $\mathrm{Zn}$ gehalte in drogestof van strooiselmest kan het gemiddeld $\mathrm{Cu}$ - en $\mathrm{Zn}$-gehalte in het rantsoen worden teruggerekend en worden bepaald of een overschrijding van de toegelaten gehalten aannemelijk is. Hierbij is niet te bepalen of een eventuele overschrijding veroorzaakt wordt door een te hoog gehalte in het voer of door verstrekking via het drinkwater, maar voor de controlerende instantie is dit niet primair van belang omdat de normstelling betrekking heeft op het complete rantsoen, inclusief aanvullende voeders via drinkwater.

De betrouwbaarheid van de berekende gehalten in de strooiselmest wordt mede bepaald door de kwaliteit van de invoer. Het is van groot belang deze zoveel mogelijk op bedrijfsgegevens te baseren. Hierbij hebben met name de gebruikte hoeveelheid strooisel (drogestof), eventueel optreden van broei in de mest en de verteerbaarheid van het voer een grote invloed. De eerste twee kunnen bij het bedrijfsbezoek worden vastgesteld of ingeschat, voor de verteerbaarheid van het voer moet een gemiddelde waarde met een veiligheidsmarge worden gebruikt. Omdat de invloed van het strooisel afneemt gedurende het groeitraject wordt geadviseerd deze methode op basis van mestanalyse vanaf circa vier weken leeftijd toe te passen.

De kwaliteit of betrouwbaarheid van de mestanalyses heeft eveneens een belangrijke invloed op de vergelijking met modelberekeningen. We adviseren hiervoor het monsterprotocol in Bijlage 7 als richtlijn te gebruiken, waarbij submonsters van 10-15 representatieve plaatsen in een stal worden genomen en worden samengevoegd tot een te analyseren verzamelmonster.

De eerste resultaten van het model in combinatie met mestanalyses geven een goed perspectief op de praktische bruikbaarheid. Voor toekomstige ondersteuning van controles op Cu en Zn-gebruik adviseren we eerst een gebruik onder praktijkomstandigheden. Daarnaast is het nodig enkele veiligheidsmarges aan te houden om een ondergrens voor $\mathrm{Cu}$ en $\mathrm{Zn}$-gehalten in strooiselmest te berekenen die met grote zekerheid duiden op een overschrijding van toegelaten gehalten in het rantsoen. 


\section{Literatuur}

Aarnink, A.J.A., J. van Harn, K. Blanken en N.W.M. Ogink, 2016. Ontwikkeling van een rekentool om de ammoniakemissie uit vleeskuikenstallen te kunnen voorspellen. Wageningen Livestock Research, Rapport 990 blz. 72.

Anonymous, 2009. Afsprakenkader Vleeskuikenrichtlijn. http://www.minlnv.nl/txmpub/files/?p_file_id=43482.

Aviagen, Ross Nutrition Supplement 2009. http://en.aviagen.com/assets/Tech_Center/Ross_Broiler/Ross_Nutrition_Supplement.pdf

Aviagen, 2014. ROSS 308 BROILER: Nutrition Specifications. http://en.aviagen.com/assets/Tech_Center/Ross_Broiler/Ross308BroilerNutritionSpecs2014EN.pdf

Bikker, P., A.W. Jongbloed, A.M. van Vuuren, 2013. De bepaling van TAN-excretie op varkens-, pluimvee- en melkveebedrijven. Rapport 665, Wageningen UR Livestock Research.

Cobb-vantress.com. Cobb500 Broiler Performance \& Nutrition Supplement, 2015.

EU, 2003. Verordening (EG) Nr. 1334/2003 van 25 juli 2003 tot wijziging van de toelatingsvoorwaarden voor een aantal toevoegingsmiddelen van de groep sporenelementen in diervoeders. Publicatieblad van de Europese Unie L187, 11-15.

EU, 2016. Uitvoeringsverordening (EU) 2016/1095. Publicatieblad van de Europese Unie L 182/7

GfE (Gesellschaft für Ernährungsphysiologie) 1999: Energie- und Nährstoffbedarf landwirtschaftlicher Nutztiere Nr. 7: Legehennen und Masthühner (Broiler); DLG-Verlag Frankfurt/M.

Harn, van J., H.E. Ellen, J.W. van Riel en J.W.H. Huis in 't Veld, 2015. Effect emissiearme huisvestingsystemen op uitval en voetzoollaesiescore bij vleeskuikens. Wageningen, Wageningen UR (University \& Research centre) Livestock Research, Livestock Research Rapport 832.

Van der Hoeven-Hangoor, E., N.D. Paton, I.B. van de Linde, M.W.A. Verstegen en W.H. Hendriks, 2013. Moisture content in broiler excreta is influenced by excreta nutrient contents. Journal of Animal Science. 2013.91:5705-5713

Hotsma, P.H., W.J. Bruins, E.J.R. Maathuis, 1996. Gehalten aan zware metalen in meststoffen. IKC-L, Ede no. 27, 28 pp.

Jansman, A.J.M. en J.Th.M. van Diepen, 2010. Validatie van een nieuw netto energiesysteem voor vleeskuikens. Vertrouwelijk rapport 225

Jong, I.C., 2018. (in press)

Jongbloed, A.W., J. de Jong, P. Vereijken en M. van der Voort, 2012. Opsporing van te hoge koper-en zinkgehalten in varkensvoer via fecesonderzoek. RIKILT Rapport 2011.018.

KWIN-Veehouderij 2017-2018 (2017). Kwantitatieve informatie veehouderij 2017-2018. ISSN 15708594.

Leeson, S., 2009. Copper metabolism and dietary needs - review. World's Poultry Science Journal, Vol. 65. p. 353-366

Lourens, A., 2009. Transport van vleeskuikens: welzijnsvoordelen van de Korte Vleeskuikenketen. Wageningen UR Livestock Rapport 330.

McDowell, L.R., 1992. Minerals in Animal Nutrition. Academic Press Limited, London.

Middelkoop, van J.H., 1993. Hoeveel mest produceert een kip?. Praktijkonderzoek voor de Pluimveehouderij 93/3, p. 7-9.

Mohanna, C. en Y. Nys, 1998. Influence of age, sex and cross on body concentrations of trace elements (zinc, iron, copper and manganese) in chickens. Br. Poultry Sci. 39, 536-543.

Nielsen, F.H., 2012. History of zinc in agriculture. Advances in Nutrition 3, p. 783-789.

NRC, 1994. Nutrient requirements of domestic animals. Nutrient requirements of poultry. National Research Council, National Academic Press Washington.

Richtlijn nr. 2007/43/EG: richtlijn nr. 2007/43//EG van de Raad van de Europese Unie van 28 juni 2007 tot vaststelling van minimumvoorschriften voor de bescherming van vleeskuikens.

Publicatieblad van de Europese Unie L182, 19-28 (PbEU L 182). 
Römkens, P.F.A.M. en R.P.J.J. Rietra, 2008. Zware metalen en nutriënten in dierlijke mest in 2008; Gehalten aan $\mathrm{Cd}, \mathrm{Cr}, \mathrm{Cu}, \mathrm{Hg}, \mathrm{Ni}, \mathrm{Pb}, \mathrm{Zn}, \mathrm{As}, \mathrm{N}$ en $\mathrm{P}$ in runder-, varkens en kippenmest. Alterrarapport 1729.

Schlegel, P., and H. Menzi, 2011 Nitrogen and mineral contents in broilers. 62nd Annual Meeting of European Federation of Animal Science, Stavenger 2011, p 63

Veldkamp, T., J.T.M. van Diepen en M.M. van Krimpen, 2014. Evaluation of nutrient digestibility and content of metabolisable energy of 15 feedstuffs for broilers. Livestock Research Report 486.

Ven, van de L.J.F., A.V. Van Wagenberg, P.W.G. Groot Koerkamp, B. Kemp en H. van den Brandt, 2009. Effects of a combined hatching and brooding system on hatchability, chick weight, and mortality in broilers. Poultry Science 88: 2273-2279.

Versteegh, H.A.J. en A.W. Jongbloed. Het gehalte aan droge stof, as, stikstof, calcium, fosfor, kalium, koper en zink in vleeskuikens op drie leeftijden. Rapport ID-Lelystad No. 99.042.

Vieira, S.L. and E.T. Moran Jr., 1998. Eggs and chicks from broiler breeders of extremely different age. J. Appl. Poultry Res. 7, 372-376.

Westhoek, H.J., L. Beijer, W.J. Bruins, P.H. Hotsma, J.W.M. Janssen, E.J.R. Maathuis, 1996. Aan- en afvoerbalansen van zware metalen van Nederlandse landbouwgronden. IKC-L, Ede no. 28, 61 pp.

Zoons, J., 2009. Langjarig onderzoek strooiselmaterialen. Sectormiddag vleeskuikenhouderij 2009.

Broiler Performance \& Nutrition Supplement Cobb 500, 2012. http://www.cobb-vantress.com/docs/default-source/cobb-500-guides/cobb500-broilerperformance-nutrition-supplement-(english)8ACAC5E6EA12EBEE36DDEAC9.pdf

Hubbard Broiler Management Guide, 2015. Hubbard Classic, Hubbard Flex and Hubbard Yield. http://www.hubbardbreeders.com/media/hubbard_broiler_management_guide_078897700_094 5_07012015.pdf 


\section{Bijlage 1 Het Vleeskuikenbesluit}

Sinds begin 2011 heeft de reguliere vleeskuikenhouderij te maken met de regels van het zogenoemde Vleeskuikenbesluit. In dit Vleeskuikenbesluit zijn regels voor de huisvesting van vleeskuikens vastgelegd, gebaseerd op de Europese welzijnsrichtlijn (Directive 2007/43/EC). Deze richtlijn gaat uit van een maximum bezetting in vleeskuikenstallen van $33 \mathrm{~kg}$ per vierkante meter. Als

vleeskuikenhouders voldoen aan extra eisen op het gebied van huisvesting, vakmanschap, uitval, e.d. kan deze bovengrens omhoog naar 39 of, maximaal, $42 \mathrm{~kg}$.

In het kort komt het erop neer dat een vleeskuikenhouder mag produceren bij een bezetting tot $39 \mathrm{~kg} / \mathrm{m}^{2}$, mits:

- Hij dit vooraf heeft gemeld aan de bevoegde autoriteit

- Hij een beschrijving van stal opstelt waarin o.a. afmeting, voer- en watervoorziening, ventilatie-, koel-, verwarming- en alarmsysteem, vloertype, e.d. van de stal worden beschreven.

- Het stalklimaat aan de volgende eisen voldoet:

- staltemperatuur $<$ buitentemperatuur $+3^{\circ} \mathrm{C}$ (bij een buitentemperatuur hoger dan $30^{\circ} \mathrm{C}$ )

- gemiddelde RV $<70 \%$ (als buitentemperatuur $<10^{\circ} \mathrm{C}$ )

$-\mathrm{CO}_{2}<3000 \mathrm{ppm}$

$-\mathrm{NH}_{3}<20 \mathrm{ppm}$

Wil een vleeskuikenhouder een bezetting hanteren van maximaal $42 \mathrm{~kg} / \mathrm{m}^{2}$ dan moet hij, naast de genoemde criteria voor $39 \mathrm{~kg} / \mathrm{m}^{2}$, voldoen aan de volgende eisen:

- Uitval

De uitval moet gedurende 7 opeenvolgende ronden lager zijn dan:

$1 \%+0,06 \times$ slachtleeftijd dieren ( $=3,40 \%$ op 40 dagen)

Indien de uitval hoger is dan kan de Nederlandse Voedsel- en Warenautoriteit (NVWA) besluiten de maximale bezetting te verlagen naar maximaal $39 \mathrm{~kg} / \mathrm{m}^{2}$.

- Aanvullende welzijnseisen m.b.t voetzoollaesies

Vanaf 2013 gelden er normen voor voetzoollaesies. De mate en ernst van voorkomen van voetzoollaesies bij een koppel vleeskuikens wordt uitgedrukt in de zgn. voetzoollaesiescore. Indien over een jaar genomen de gemiddelde VZL-score in een stal lager is dan 80 punten dan zijn er relatief weinig problemen en mag in deze stal een bezetting worden gehanteerd tot $42 \mathrm{~kg} / \mathrm{m}^{2}$. Ligt de score tussen de 80 punten en 120 punten dan moet een bedrijf een verbeterplan opstellen met de maatregelen die men wil nemen om de VZL-score terug te brengen naar max. 80 punten. Is de gemiddelde VZL-score hoger dan 120 punten dan is er sprake van een ernstig probleem en dient, naast het opstellen van een verbeterplan, de maximale bezetting op het bedrijf terug worden teruggebracht naar maximaal $39 \mathrm{~kg} / \mathrm{m}^{2}$.

Let wel: om een bezetting te mogen hanteren tot $42 \mathrm{~kg} / \mathrm{m}^{2}$ moet een bedrijf voldoen aan beide criteria, dus zowel aan de uitval- als de voetzoollaesie-eis. 


\section{Bijlage 2 Voetzoollaesies}

\section{Wat zijn voetzoollaesies?}

Voetzoollaesies zijn aantastingen van de opperhuid van de voetzool van vleeskuikens. De ernst van deze aantasting kan variëren van een oppervlakkige (kleine) verkleuring van de huid tot een diepe open wond. Wanneer de huid tot in de diepere lagen is aangetast worden de laesies pijnlijk en wordt het welzijn van het dier aangetast. Kuikens met pijnlijke laesies bewegen minder, waardoor de ernst van de laesies toeneemt. Daarnaast is de kans groter op het ontstaan van andere irritaties zoals borst- en hakirritaties. Ook komen de kuikens minder naar de voerbak, waardoor de groei afneemt. De belangrijkste oorzaak van voetzoollaesies is een slechte kwaliteit van het strooisel in de stal. Factoren welke een invloed hebben op het ontstaan van nat strooisel zijn: buiten- en stalklimaat (temperatuur en RV), licht en lichtverdeling, ventilatie, voersamenstelling, type strooisel, drinkwaterkwaliteit, drinkwatersysteem en het optreden van verteringsproblemen, e.d.. Een aantal van deze factoren heeft een vleeskuikenhouder niet in de hand, op andere kan hij invloed uitoefenen.

\section{Voetzoollaesiescore}

De ernst van voetzoollaesies in een stal / koppel wordt uitgedrukt in een getal: de voetzoollaesiescore. Hoe wordt de voetzoollaesiescore (VZL-score) berekend?

De voetzoollaesie score (VZL score), is een maat waarmee het voorkomen en ernst van voetzoollaesies van een koppel kan worden uitgedrukt en deze wordt als volgt berekend:

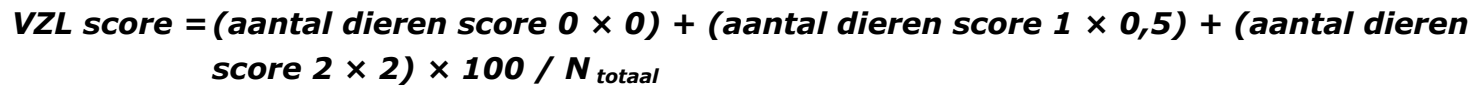

waarbij $\mathrm{N}_{\text {totaal }}$ het totaal aantal beoordeelde dieren is.

De VZL score kan dus variëren van 0 (wanneer er helemaal geen laesies zijn) en 200, dit is het geval wanneer $100 \%$ van de voetzolen wordt gescoord in klasse 2. 


\section{Bijlage 3 Drinkwatersupplementen}

Overzicht van een aantal op de markt beschikbare drinkwatersupplementen met koper en/of zink, bestemd voor pluimvee.

\begin{tabular}{|c|c|c|c|c|c|c|c|}
\hline Naam product & Leverancier & Vorm koper & Vorm zink & $\begin{array}{r}\text { Cu gehalte } \\
(\mathrm{mg} / \mathrm{l})\end{array}$ & $\begin{array}{r}\text { Zn gehalte } \\
(\mathrm{mg} / \mathrm{l})\end{array}$ & $\begin{array}{r}\text { Advies dosering } \\
(\mathrm{ml} / 1000 \mathrm{~L})\end{array}$ & Opmerking \\
\hline Osteosol AD & Dopharma & $\begin{array}{l}\text { Koperhydroxycarbonaat } \\
\text { monohydraat }\end{array}$ & Zinkacetaat-dihydraat & 718 & 4590 & 1000 & \\
\hline Copper Plus AD & Dopharma & Koper(II)sulfaat, pentahydraat & & 15000 & & 250 & \\
\hline Vitaminsol multi & Dopharma & Cu-gluconaat & Zn-gluconaat & 280 & 574 & 500 & $\begin{array}{l}\text { Diergeneesmiddel, } \\
\text { verstrekking } 5 \mathrm{~d} \text {. }\end{array}$ \\
\hline Agrocid Super Oligo & Cid Lines & Koper(II)chloride, dihydraat & zinkchloride, monohydraat & 2100 & 2500 & $300-500$ & \\
\hline Pro-Mac Pluimvee & Kanters & $\begin{array}{l}\text { koper chelaat van glycine, } \\
\text { koperchloride dihydraat }\end{array}$ & $\begin{array}{l}\text { zink chelaat van glycine, } \\
\text { zinkchloride }\end{array}$ & 291 & 1340 & 1000 & \\
\hline Nutriforte Pluimvee & Kanters & koper chelaat van glycine & zinkchloride & 2500 & 3600 & 1000 & \\
\hline Intesti-Flora & Kanters & koper chelaat van glycine & - & 54037 & - & Afh. concentratie eindvoer & \\
\hline Intesti-Forte & Kanters & koper chelaat van glycine & zink chelaat van glycine & 65 & 81225 & Afh. concentratie eindvoer & \\
\hline Intesti-Fit & Kanters & koper chelaat van glycine & zink chelaat van glycine & 62045 & 86 & Afh. concentratie eindvoer & \\
\hline Intesti-Mix & Kanters & koper chelaat van glycine & zink chelaat van glycine & 36000 & 36000 & Afh. concentratie eindvoer & \\
\hline Ultimate acid & Kanters & koper chelaat van glycine & zink chelaat van glycine & 2500 & 3000 & $\mathrm{pH}$ gestuurd & \\
\hline Premium acid & Kanters & Kopersulfaat pentahydraat & zink chelaat van glycine & 1273 & 83 & $\mathrm{pH}$ gestuurd & \\
\hline Kanters pH support & Kanters & Kopersulfaat pentahydraat & zinkchloride & 2500 & 650 & $\mathrm{pH}$ gestuurd & \\
\hline Kanters $\mathrm{pH}+$ & Kanters & $\begin{array}{l}\text { koper chelaat van glycine, } \\
\text { gehydrateerd }\end{array}$ & - & 2500 & - & $\mathrm{pH}$ gestuurd & \\
\hline Selko $\mathrm{pH}$ & Selko & Koper(II)sulfaat, pentahydraat & Zinkacetaat-dihydraat & 2240 & 596 & $1000-2000$ & \\
\hline Daaquasafe & Daavision BV & Koper(II)sulfaat, pentahydraat & Zinkacetaat-dihydraat & 1273 & 1148 & $1000-2000$ & \\
\hline MS F\&F Support & MS Schippers & & & & 2800 & 1000 & $\begin{array}{l}\text { 3d; max. } 18,6 \% \text { in } \\
\text { dagrantsoen. }\end{array}$ \\
\hline
\end{tabular}




\begin{tabular}{|c|c|c|c|c|c|c|c|}
\hline Naam product & Leverancier & Vorm koper & Vorm zink & $\begin{array}{r}\text { Cu gehalte } \\
(\mathrm{mg} / \mathrm{l})\end{array}$ & $\begin{array}{r}\mathrm{Zn} \text { gehalte } \\
(\mathrm{mg} / \mathrm{l})\end{array}$ & $\begin{array}{r}\text { Advies dosering } \\
(\mathrm{ml} / \mathbf{1 0 0 0 \mathrm { L }})\end{array}$ & Opmerking \\
\hline MS Koper Facet & MS Schippers & Koperchelaat van glycinehydraat & & 2500 & & 3000 & $\begin{array}{l}\text { max. } 18,6 \% \text { in } \\
\text { dagrantsoen. }\end{array}$ \\
\hline Goldfeed Cu & MS Schippers & Koper(II)sulfaat, pentahydraat & zink chelaat van aminozuren & 2500 & 125 & $1000-2000$ & $\begin{array}{l}\text { max. } 18,6 \% \text { in } \\
\text { dagrantsoen. }\end{array}$ \\
\hline MS Microplus Extra & MS Schippers & Koper(II)chloride, dihydraat & zinkchloride, monohydraat & 600 & 5000 & 1000 & $\begin{array}{l}\text { max. } 18,6 \% \text { in } \\
\text { dagrantsoen. }\end{array}$ \\
\hline MS Zink Facet & MS Schippers & & zink chelaat van glycine & & 15000 & $600-1000$ & $\begin{array}{l}\text { max. } 18,6 \% \text { in } \\
\text { dagrantsoen. }\end{array}$ \\
\hline
\end{tabular}




\section{Bijlage 4 Gemiddelde voersamenstelling}

Samenstelling van het gemiddeld vleeskuikenvoer gebruikt voor de berekening van de drogestofverteerbaarheid. De samenstelling is een gewogen gemiddelde van een vier-fasen voerpakket (startvoer, twee groeivoeders en eindvoer) voor vleeskuikens geoptimaliseerd in vier kwartalen van 2016 ten behoeve van het berekenen van de stikstofexcretie zoals beschreven door Bikker et al. (2011).

\begin{tabular}{|c|c|}
\hline \multicolumn{2}{|l|}{ Ingrediënten, \% } \\
\hline Tarwe & 41,50 \\
\hline Mais & 18,50 \\
\hline Sojaschroot & 27,90 \\
\hline Raapzaadschroot & 2,30 \\
\hline Zonnebloemzaadschroot & 0,70 \\
\hline Tarwegries & 0,10 \\
\hline Vet dierlijk & 2,50 \\
\hline Plantaardig vet & 3,40 \\
\hline Krijt (fijn gemalen) & 1,10 \\
\hline Vitamine en mineralenpremix & 0,50 \\
\hline Fytase premix & 0,60 \\
\hline Monocalciumfosfaat & 0,30 \\
\hline Zout & 0,20 \\
\hline Natriumbicarbonaat & 0,20 \\
\hline L-Lysine HCL & 0,20 \\
\hline DL-Methionine & 0,20 \\
\hline \multicolumn{2}{|l|}{ Nutriënten, $\mathrm{g} / \mathrm{kg}$} \\
\hline Droge stof (DS) & 880 \\
\hline Verteringscoëfficiënt DS, \%1) & 73,2 \\
\hline Ruw eiwit & 206 \\
\hline Ruw vet & 78 \\
\hline Ruw celstof & 29 \\
\hline Zetmeel & 349 \\
\hline Suiker & 46 \\
\hline Ruwe as & 47 \\
\hline Omzetbare energie (OE, kcal) & 2817 \\
\hline
\end{tabular}

1) Drogestofvertering gebaseerd op de verteringscoëfficiënt van ruw eiwit, ruw vet en overige koolhydraten van de ingrediënten volgens de CVB veevoedertabel, waarbij wordt verondersteld dat ruwe celstof voor vleeskuikens volledig onverteerbaar is. De verteerbaarheid of retentie van de anorganische stof is gebaseerd op het asgehalte in het voer, de voeropname en de retentie in het dier en bedroeg $31 \%$. 


\section{Bijlage $5 \mathrm{Cu}$ en $\mathrm{Zn}$ in vleeskuikens}

Koper en zinkgehalten in vleeskuikens bij uitkomst uit het ei en bij slachtrijpe dieren op basis van enkele wetenschappelijke publicaties ${ }^{1}$.

\begin{tabular}{|c|c|c|c|c|c|c|c|c|c|}
\hline Author & Breed & $\mathrm{n}$ & rep & Sex & Age & LW & DM & $\mathrm{Zn}$ & $\mathrm{Cu}$ \\
\hline & & & & & d & $\mathbf{g}$ & $\mathbf{g} / \mathbf{k g}$ & $\mathbf{m g} / \mathbf{k g}$ & $\mathbf{m g} / \mathbf{k g}$ \\
\hline \multicolumn{10}{|l|}{ Day-old chickens } \\
\hline Mohanna \& Nys, 1998 & Starbro Shaver & 1 & 15 & M & 0 & 42 & 242 & 12,9 & 1,03 \\
\hline Mohanna \& Nys, 1998 & Starbro Shaver & 1 & 15 & $\mathrm{~F}$ & 0 & 42 & 238 & 13,7 & 1,30 \\
\hline Mohanna \& Nys, 1998 & Vedette & 1 & 15 & M & 0 & 42 & 234 & 15,5 & 1,37 \\
\hline Mohanna \& Nys, 1998 & Vedette & 1 & 15 & $\mathrm{~F}$ & 0 & 42 & 237 & 15,5 & 1,19 \\
\hline Vieira and Moran, 1998 & RossxRoss & 15 & 2 & MF & 1 & 43 & 266 & 11,6 & 1,70 \\
\hline Vieira and Moran, 1998 & RossxRoss & 15 & 2 & MF & 1 & 50 & 266 & 11,8 & 2,31 \\
\hline \multicolumn{10}{|l|}{ Broilers for slaughter } \\
\hline Versteegh \& Jongbloed, 1999 & Commercial & 6 & 6 & MF & 35 & 1613 & 335 & 21,1 & $(12,0)$ \\
\hline Versteegh \& Jongbloed, 1999 & Commercial & 6 & 6 & MF & 35 & 1625 & 336 & 20,7 & $(11,7)$ \\
\hline Versteegh \& Jongbloed, 1999 & Commercial & 6 & 6 & MF & 35 & 1652 & 340 & 23,2 & $(13,1)$ \\
\hline Mohanna \& Nys, 1998 & Vedette & 1 & 15 & $\mathrm{~F}$ & 40 & 1813 & 390 & 14,7 & 1,19 \\
\hline Mohanna \& Nys, 1998 & Starbro Shaver & 1 & 15 & $\mathrm{~F}$ & 40 & 1847 & 386 & 14,0 & 1,30 \\
\hline Versteegh \& Jongbloed, 1999 & Commercial & 6 & 6 & MF & 42 & 1985 & 353 & 19,2 & $(11,4)$ \\
\hline Mohanna \& Nys, 1998 & Vedette & 1 & 15 & M & 40 & 2098 & 372 & 14,4 & 1,37 \\
\hline Mohanna \& Nys, 1998 & Starbro Shaver & 1 & 15 & M & 40 & 2106 & 359 & 15,0 & 1,03 \\
\hline Versteegh \& Jongbloed, 1999 & Commercial & 6 & 6 & MF & 42 & 2108 & 351 & 20,1 & $(12,0)$ \\
\hline Versteegh \& Jongbloed, 1999 & Commercial & 6 & 6 & MF & 42 & 2122 & 342 & 20,8 & $(12,3)$ \\
\hline Versteegh \& Jongbloed, 1999 & Commercial & 6 & 6 & MF & 48 & 2414 & 355 & 20,3 & $(11,3)$ \\
\hline Mohanna \& Nys, 1998 & Starbro Shaver & 1 & 15 & $\mathrm{~F}$ & 50 & 2414 & 416 & 14,9 & 1,31 \\
\hline Versteegh \& Jongbloed, 1999 & Commercial & 6 & 6 & MF & 48 & 2450 & 360 & 20,4 & $(11,6)$ \\
\hline Versteegh \& Jongbloed, 1999 & Commercial & 6 & 6 & MF & 48 & 2508 & 341 & 20,7 & $(12,5)$ \\
\hline Mohanna \& Nys, 1998 & Starbro Shaver & 1 & 15 & M & 50 & 2991 & 382 & 15,8 & 1,25 \\
\hline Schlegel \& Menzi, 2011 & $\begin{array}{l}\text { Ross, Hubbard, } \\
\text { Isa JA }\end{array}$ & 1 & 27 & $?$ & $?$ & $\begin{array}{l}840- \\
2190\end{array}$ & 355 & 21,3 & 1,75 \\
\hline
\end{tabular}

Bij de kolommen: rep = aantal replicates (herhalingen); $n=$ aantal dieren per herhaling; bij sekse: $M=$ male, $F=$ female.

De kopergehalten gerapporteerd door Versteegh en Jongbloed (1999) zijn onrealistisch hoog en niet meegenomen in de berekening van het gemiddeld kopergehalte in vleeskuikens. 


\section{Bijlage 6 Standaard curve}

Standaard curve voor gewicht, voeropname en uitval.

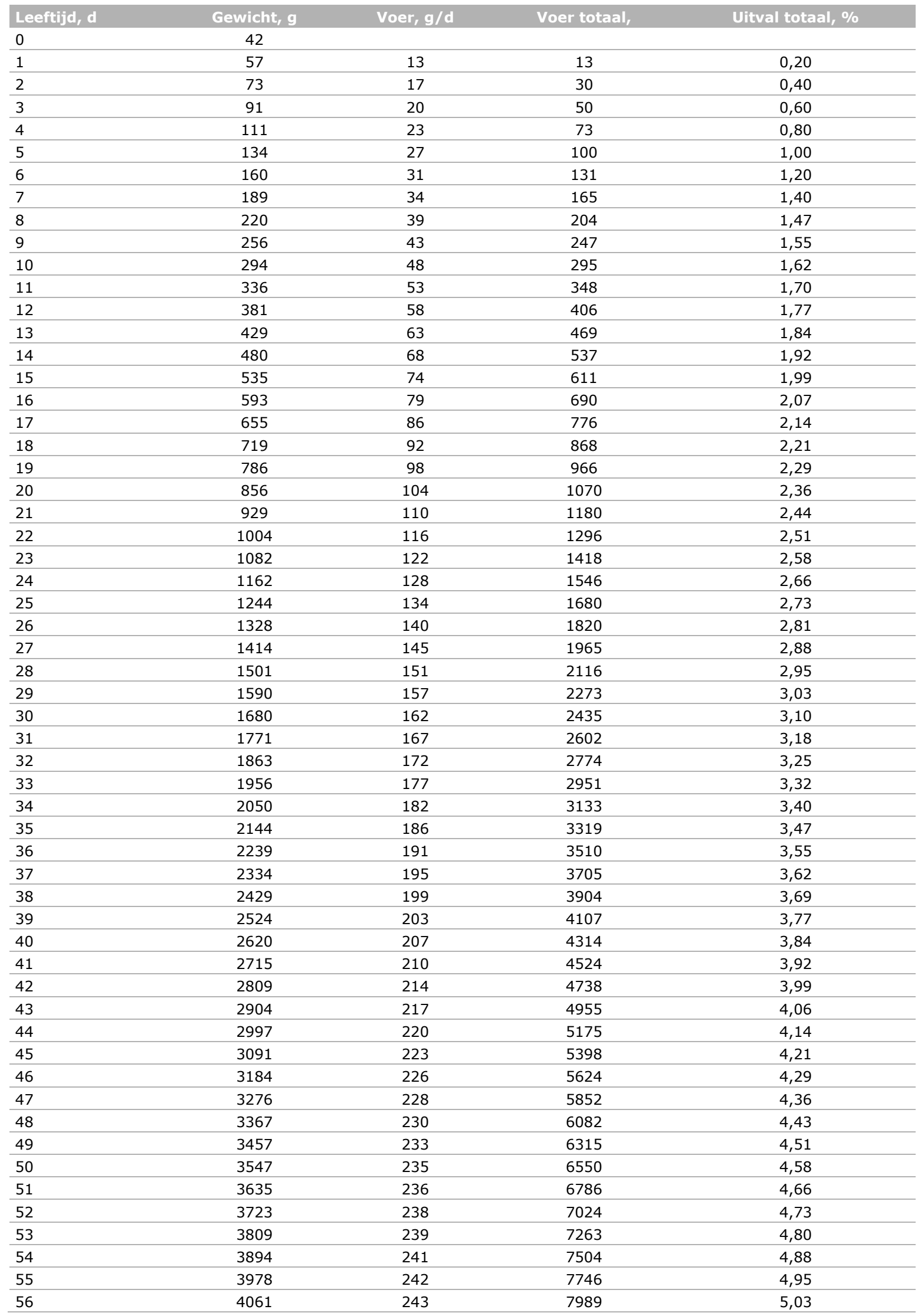




\section{Bijlage 7 Bemonstering strooiselmest}

Het nemen van een representatief monster van strooiselmest in een vleeskuikenstal is niet eenvoudig. De moeilijkheid is dat er in een stal verschillende zones zijn. Er zijn zones rondom de drinklijnen, voerlijnen en gebieden waar geen invloed is van de drink- en/of voerlijn. Verder kan het zo zijn dat de strooiselkwaliteit kan verschillen op verschillende locaties/plekken in de stal. Het is belangrijk dat de monsters representatief voor de gehele stal. Het is daarom van belang dat de deelmonsters steeds in dezelfde verhouding moeten genomen worden tot de oppervlakte die ze vertegenwoordigen.

Bijvoorbeeld: Indien water- en voederlijnen $20 \%$ van de oppervlakte uitmaken in de stal, dan moeten de deelmonsters eveneens 20\% vertegenwoordigen ( 2 van de 10 , of 3 van de 15 deelmonsters moeten dan genomen worden in deze zones). Het is van belang dat er een monster wordt genomen van de totale strooiselmestlaag, oftewel over de volledige diepte van de strooiselmestlaag (dus tot aan de betonnen vloer). Hieronder wordt een monstername methode beschreven welke gehanteerd zou kunnen worden om een representatief monster te nemen in een stal.

Bemonsteringsmethode:

1. Allereerst de totale oppervlakte van de stal bepalen. De lengte en breedte van de stal zijn in de meeste gevallen precies bekend bij de pluimveehouder.

2. Vervolgens wordt het aantal water- en voederlijnen geteld en er wordt een zo goed mogelijke inschatting gemaakt van de oppervlakte van de mest, die door elk van deze lijnen beïnvloed wordt. Als vuistregel kan worden aangehouden dat een drinklijn 0,75 m en een voerlijn 1,25 m beïnvloed.

3. Daarna kan berekend worden in welke verhouding de verschillende kwaliteiten mest in het monster betrokken moeten worden. Deze moet dezelfde zijn als de verhouding waarin de verschillende kwaliteiten in de stal voorkomen.

4. In totaal wordt op ongeveer 10 - 15 punten in de stal een submonster genomen. Deze monsters worden genomen op $1 / 3$ en $2 / 3$ van de lengterichting van de stal ( 2 diagonalen). Bij lange stallen ( $>70 \mathrm{~m}$ ) zou men op 3 diagonalen ( $1^{\mathrm{e}}$ op $1 / 4,2^{\mathrm{e}}$ op $2 / 4$ en de $3^{\mathrm{e}}$ op $3 / 4$ van de lengterichting) in de stal kunnen bemonsteren. Het precieze aantal diagonalen en monsterpunten is afhankelijk van de verhouding tussen de verschillende mestkwaliteiten waaraan voldaan moet worden. Uitgangspunt is dat er op iedere diagonaal evenveel submonsters genomen worden. In het voorbeeldgeval betekent dit dat er op 10 plaatsen een submonster genomen wordt, waarvan 2 bij de voederlijn, 3 bij de waterlijn en 5 in de rest van de stal. De punten in de stal, waar bemonsterd wordt, staan in onderstaande figuur aangeduid met een cijfer (1...10). De punten zijn zo gekozen, dat alle delen van de stal ongeveer evenveel aan bod komen.

De deel-/submonsters worden genomen met een door het bedrijf geleverde schep/spade/boor. Hierdoor ontstaat er tussen bedrijven variatie in de grootte van de submonsters. Dit is echter geen bezwaar, omdat niet de totale hoeveelheid mest belangrijk is in een monster, maar de verhouding waarin de verschillende kwaliteiten in het monster worden betrokken. Dit betekent dat ieder submonster binnen een stal eenzelfde oppervlakte moet vertegenwoordigen.

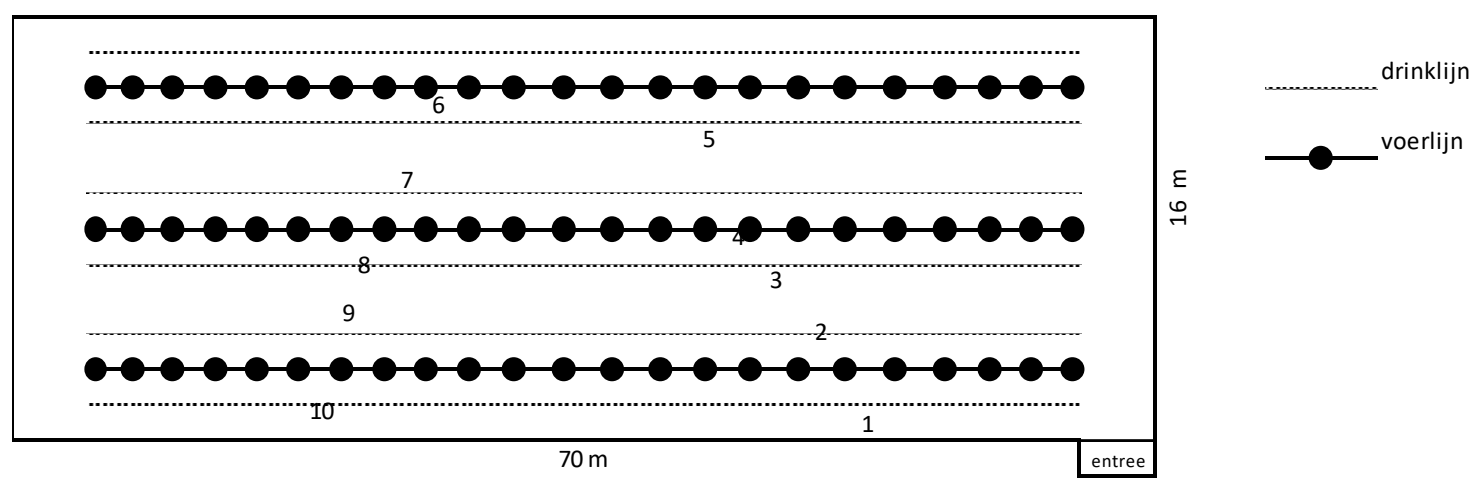


5. De submonsters worden in een schone en droge emmer of plastic zak gedaan. Als alle submonsters genomen zijn, wordt de inhoud van de emmer of plastic zak grondig gehomogeniseerd, waarna een representatief monster en twee reservemonsters worden genomen voor analyse. Zo nodig kan het homogeniseren van het verzamelmonster door het lab worden gedaan, waarbij als consequentie relatief grote hoeveelheden strooiselmest naar het lab moeten worden gestuurd.

6. Bij dit type monstername moet worden aangetekend, dat er van de procedure afgeweken kan worden, als hiertoe aanleiding bestaat. Dit kan bijvoorbeeld voorkomen als er zich in een stal lekkage bij een waterlijn heeft voorgedaan. Als deze lekkage zich bevindt op een monsterpunt en niet representatief is voor de mest onder de waterlijn, wordt er uitgeweken naar een ander punt op dezelfde waterlijn. In het merendeel van de monsternames kan echter gewoon de hierboven beschreven procedure aangehouden worden. 
RIKILT Wageningen University \& Research Postbus 230

6700 AE Wageningen

T 0317480256

www.wur.nl/rikilt

RIKILT-rapport 2018.006
De missie van Wageningen University \& Research is 'To explore the potential of nature to improve the quality of life'. Binnen Wageningen University \& Research bundelen Wageningen University en gespecialiseerde onderzoeksinstituten van Stichting Wageningen Research hun krachten om bij te dragen aan de oplossing van belangrijke vragen in het domein van gezonde voeding en leefomgeving. Met ongeveer 30 vestigingen, 5.000 medewerkers en 10.000 studenten behoort Wageningen University \& Research wereldwijd tot de aansprekende kennisinstellingen binnen haar domein. De integrale benadering van de vraagstukken en de samenwerking tussen verschillende disciplines vormen het hart van de unieke Wageningen aanpak. 



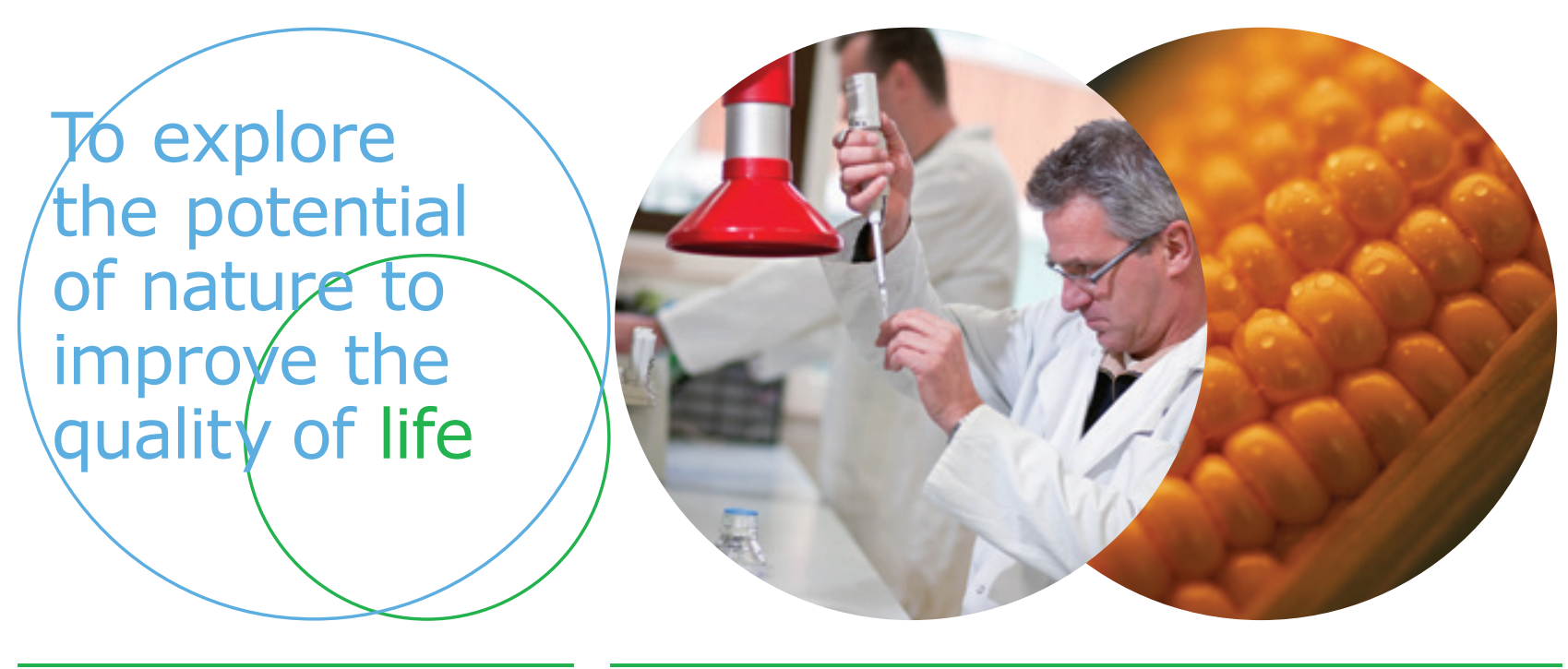

RIKILT Wageningen University \& Research Postbus 230

6700 AE Wageningen

T 0317480256

www.wur.nl/rikilt

RIKILT-rapport 2018.006
De missie van Wageningen University \& Research is 'To explore the potential of nature to improve the quality of life'. Binnen Wageningen University \& Research bundelen Wageningen University en gespecialiseerde onderzoeksinstituten van Stichting Wageningen Research hun krachten om bij te dragen aan de oplossing van belangrijke vragen in het domein van gezonde voeding en leefomgeving. Met ongeveer 30 vestigingen, 5.000 medewerkers en 10.000 studenten behoort Wageningen University \& Research wereldwijd tot de aansprekende kennisinstellingen binnen haar domein. De integrale benadering van de vraagstukken en de samenwerking tussen verschillende disciplines vormen het hart van de unieke Wageningen aanpak. 